\title{
Contribution of miRNAs in the Pathogenesis of Breast Cancer
}

\author{
Soudeh Ghafouri-Fard ${ }^{1}$, Ali Khanbabapour Sasi ${ }^{2}$, Atefe Abak ${ }^{3}$, Hamed Shoorei ${ }^{4}$, \\ Ali Khoshkar ${ }^{5}$ and Mohammad Taheri ${ }^{6 *}$ \\ ${ }^{1}$ Department of Medical Genetics, School of Medicine, Shahid Beheshti University of Medical Sciences, Tehran, Iran, \\ ${ }^{2}$ Biochemistry Group, School of Medicine, Golestan University of Medical Science, Gorgan, Iran, ${ }^{3}$ Men's Health and \\ Reproductive Health Research Center, Shahid Beheshti University of Medical Sciences, Tehran, Iran, ${ }^{4}$ Department of \\ Anatomical Sciences, Faculty of Medicine, Birjand University of Medical Sciences, Birjand, Iran, ${ }^{5}$ Department of Surgery, \\ Loghman Hakim Hospital, Shahid Beheshti University of Medical Sciences, Tehran, Iran, 6 Skull Base Research Center, \\ Loghman Hakim Hospital, Shahid Beheshti University of Medical Sciences, Tehran, Iran
}

\section{OPEN ACCESS}

Edited by:

Pasquale Simeone,

University of Studies G. d'Annunzio

Chieti and Pescara, Italy

Reviewed by: Javier Gaytan,

IMSS, Mexico

Gisela Ceballos,

Instituto Nacional de Medicina Genómica (INMEGEN), Mexico

*Correspondence:

Mohammad Taheri Mohammad_823@yahoo.com

Specialty section: This article was submitted to Cancer Genetics, a section of the journal

Frontiers in Oncology

Received: 01 September 2021 Accepted: 18 October 2021 Published: 05 November 2021

Citation:

Ghafouri-Fard $S$, Khanbabapour Sasi A, Abak A, Shoorei $H$, Khoshkar $A$ and Taheri $M$ (2021) Contribution of miRNAs in the Pathogenesis of Breast Cancer.

Front. Oncol. 11:768949. doi: 10.3389/fonc.2021.768949
Breast cancer is the most frequently diagnosed cancer among females. Gene expression profiling methods have shown the deregulation of several genes in breast cancer samples and have confirmed the heterogeneous nature of breast cancer at the genomic level. microRNAs (miRNAs) are among the recently appreciated contributors in breast carcinogenic processes. These small-sized transcripts have been shown to partake in breast carcinogenesis through modulation of apoptosis, autophagy, and epithelialmesenchymal transition. Moreover, they can confer resistance to chemotherapy. Based on the contribution of miRNAs in almost all fundamental aspects of breast carcinogenesis, therapeutic intervention with their expression might affect the course of this disorder. Moreover, the presence of miRNAs in the peripheral blood of patients potentiates these transcripts as tools for non-invasive diagnosis of breast cancer.

Keywords: miRNA, microRNA, breast cancer, apoptosis, biomarker

\section{INTRODUCTION}

Breast cancer is the most frequently diagnosed cancer among females. With approximately 2.3 million new cases, breast cancer accounts for $11.7 \%$ of all diagnosed cancers. In terms of cancerrelated mortalities, female breast cancer is responsible for $6.9 \%$ of mortalities and ranks fifth. Notably, the mortality rate from female breast cancer is significantly higher in developing countries compared with that in developed countries (1). This cancer has been found to be associated with a number of lifestyle and reproductive risk factors, namely, early menarche age, late menopause age, first birth high age, lower period of breastfeeding, hormone replacement therapy after menopause, taking oral contraceptive pills, alcohol intake, and obesity (2). Approximately $5-10 \%$ of breast neoplasms are associated with inherited mutations in a number of genes, particularly the BRCA1 and BRCA2 genes (3). In addition, gene expression profiling methods have shown the deregulation of several genes in breast cancer samples and have confirmed the heterogeneous nature of breast cancer at the genomic level (4). More recently, several investigations have reported the dysregulation of microRNAs (miRNAs) in breast cancer samples or plasma samples from these patients in correlation with the functional aspects of tumorigenesis (5-7). miRNAs are produced through a multistep process mediated by two RNase III proteins, namely, Drosha and Dicer $(8,9)$. 
These small-sized non-coding transcripts have been found to regulate the expression of a significant proportion of human genes and play fundamental roles in the development of human disorders (10). miRNAs mainly regulate gene expression at posttranscriptional level. Meanwhile, miRNA metabolism and functions are regulated through sophisticated mechanisms (10). Moreover, the expression of miRNA genes is regulated at the transcriptional level through mechanisms similar to the regulatory mechanisms of protein-coding genes. This type of regulation defines the tissue- or developmental stage-specific expression of miRNAs. Most notably, miRNAs can suppress the expression of mRNAs that code factors participating in miRNA biogenesis; thus, they contribute in autoregulatory feedback paths (10). The expression of miRNAs has been reported to be altered in breast cancer samples. As an illustration, recent studies have detected the aberrant expression of miR-221 and miR-222 in breast malignancy (11, 12). In the current review, we describe the impact of miRNAs in breast carcinogenesis and explain their participation in the regulation of apoptosis, autophagy, epithelial-mesenchymal transition (EMT), and resistance to chemotherapy. These processes have important roles in the pathogenesis of cancer. EMT is regarded as a key participant in the invasion and metastasis of cancers. Thus, identifying the main regulators of this process has important implications in cancer treatment. Autophagy has dual roles in cancer progression. Its activation can provide energy and nutrient supplies during the metastatic process, which promotes cell survival in stressful situations (13). In contrast, autophagy can act as a cancer suppressor in the early phase of cancer progression and hinder metastasis through decreasing the expression of important transcription factors for EMT (13). Resistance to apoptotic signals is a key feature in cancer development (14). Moreover, defects in the apoptotic mechanisms enhance malignant transformation and induce the resistance of transformed cells to chemotherapy (14). Finally, resistance to chemotherapy is an important feature gained by tumor cells during tumor evolution, precluding cancer management.

\section{REGULATION OF APOPTOSIS BY MIRNAS IN BREAST CANCER}

Apoptosis is a coordinated process that happens in physiological and pathological contexts. Cancer is one of the contexts where lack of appropriate cell apoptosis results in the survival of malignant cells. Several pathways are involved in the regulation of apoptosis. Defects can happen at any portion of these pathways, resulting in the malignant transformation of cells, facilitation of tumor metastasis, and induction of resistance to anticancer agents (15). miR-7-5p is an example of miRNAs that regulate the apoptosis of breast cancer cells. This miRNA has been shown to target proteasome activator subunit 3 (REG $\gamma$ ), an important modulator of breast cancer and activator of protein proteolysis. The upregulation of miR-7-5p has led to the suppression of proliferation and induction of cell apoptosis in breast cancer through influencing the expression of REG $\gamma$ (16). This member of the REG family has an oncogenic function which depends on the proteolysis of p21 and p53 $(17,18)$. miR-15a and miR-16 are two other miRNAs that regulate the apoptosis of breast cancer cells. Luciferase reporter assay has confirmed the interaction between these miRNAs and 3' UTR of BMI1 transcript. Both miRNAs could suppress the expression of BMI1 at the transcript and protein levels, resulting in the downregulation of anti-apoptotic protein BCL2 and the upregulation of pro-apoptotic proteins. The forced overexpression of these miRNAs has enhanced the levels of mitochondrial reactive oxygen species (ROS), leading to impairment of mitochondrial membrane potential, release of cytochrome c into the cytosol, and activation of Caspase- 3 and Caspase-6/9. These events altogether induce the intrinsic pathway of apoptosis (19). miR-17-5p is another miRNA that has been found to induce apoptosis in breast cancer cells. Notably, the upregulation of miR-17-5p has enhanced the sensitivity of breast cancer cells to paclitaxel-associated cell apoptosis through the modulation of STAT3. Consistent with this finding, the upregulation of STAT3 has reduced the paclitaxel-associated apoptosis of MCF-7 cells. miR-17-5p has been found to enhance apoptosis through upregulating the p53 expression, which was suppressed by STAT3. Therefore, miR-17-5p suppresses STAT3 and upregulates p53 to increase breast cancer cell apoptosis (20).

Another study has demonstrated the impact of miR-23a on the suppression of apoptosis in breast cancer cells. Notably, this impact has been exerted in an independent manner from its inhibitory role on the X-linked inhibitor of apoptosis protein, the most potent anti-apoptotic member of the inhibitor-of-apoptosis proteins (21). Notably, the role of miR-23a on the enhancement of invasiveness of breast cancer cells has been verified in xenograft models (22). Several other upregulated miRNAs in breast cancer, such as miR-27a, miR-32, miR-205-3p, miR-221/ 222, and miR-1271, as well as downregulated miRNAs in breast cancer, such as miR-17-5p, miR-134, miR-139-5p, miR-200b, miR-214, miR-218, miR-543, miR-1301-3p, and miR-4458, have been found to regulate apoptosis in breast cancer cells. Table 1 shows the regulation of apoptosis by miRNAs in breast cancer. Figure 1 demonstrates that the aberrant expression of various miRNAs could contribute in adversely modulating the mitochondrial pathway of apoptosis which is involved in triggering human breast cancer.

\section{REGULATION OF AUTOPHAGY BY MIRNAS IN BREAST CANCER}

An autophagy mechanism is initiated by the establishment of autophagosomes that seizure degraded apparatuses and then fuse with lysosomes to induce recycling processes. Autophagy has dual impacts in tumor inhibition and promotion in several types of malignancies. Moreover, autophagy influences cancer stem cell properties through participating in the maintenance of stemness, regulation of tumor recurrence, and induction of 
TABLE 1 | Regulation of apoptosis by miRNAs in breast cancer.

\begin{tabular}{|c|c|c|c|c|c|c|}
\hline microRNA & $\begin{array}{l}\text { Expression } \\
\text { pattern }\end{array}$ & Samples & Cell lines & Target/pathway & Function & Reference \\
\hline $\operatorname{miR}-7-5 p$ & - & $\begin{array}{l}\text { Nude mice, BC } \\
\text { tissues }\end{array}$ & $\begin{array}{l}\text { BT549, MDA-MB- } \\
\text { 231, MDA-MB-468, } \\
\text { MCF-7, SK-BR-3, } \\
\text { T47D, HBL100, } \\
\text { MCF-10A }\end{array}$ & $\begin{array}{l}\text { REG } \gamma, \mathrm{p} 21, \mathrm{p} 27 \\
\text { Caspase-3 }\end{array}$ & $\begin{array}{l}\text { miR-7-5p, by targeting REG } \gamma \text {, could suppress cell } \\
\text { proliferation and induces apoptosis of BC cells }\end{array}$ & $(16)$ \\
\hline $\begin{array}{l}\operatorname{miR}-15 a \\
\operatorname{miR}-16\end{array}$ & - & miRTarBase & $\begin{array}{l}\text { MCF-7, MDAMB- } \\
231\end{array}$ & $\begin{array}{l}\text { BMl1, Bax, Bcl-2, } \\
\text { BID, PARP, } \\
\text { Caspase-3/9, Cyt- } \\
\text { c, p21, p53 }\end{array}$ & $\begin{array}{l}\text { miR-15a and miR-16, by suppressing oncogene BMl1, } \\
\text { could induce mitochondrial-dependent apoptosis in BC } \\
\text { cells }\end{array}$ & (19) \\
\hline$m i R-17-5 p$ & Down & - & $\begin{array}{l}\text { MCF-7, MDA-MB- } \\
231 \\
\text { MCF-7/tamoxifen, } \\
\text { MDA-MB-231/ } \\
\text { paclitaxel }\end{array}$ & $\begin{array}{l}\text { STAT } 1 / 3 / 5, \text { p21/ } \\
\text { 27/57/51/53, Bax, } \\
\text { PARP, Caspase-3 }\end{array}$ & $\begin{array}{l}\text { miR-17-5p, by targeting STAT3 through inhibiting the } \\
\text { STAT3/p53 pathway, could induce apoptosis in BC cell }\end{array}$ & (20) \\
\hline miR-23a & - & Nude mice & $\begin{array}{l}\text { MCF-7, T47D, } \\
\text { SKBR3, BT549, } \\
\text { MDA-MB-231, } \\
\text { MDA-MB-435S, } \\
\text { MCF-10A }\end{array}$ & XIAP, LC3-II/I, p62 & $\begin{array}{l}\text { miR-23a could promote survival and migration through } \\
\text { modulating XIAP-mediated autophagy in BC cells. It can } \\
\text { suppress apoptosis in breast cancer cells }\end{array}$ & $(22)$ \\
\hline $\operatorname{miR}-27 a$ & Up & $\begin{array}{l}40 \text { pairs of } B C \text { and } \\
\text { ANTs }\end{array}$ & $\begin{array}{l}\text { MCF-10A, T-47D, } \\
\text { MDA-MB-231, BT- } \\
\text { 20, MCF-7 }\end{array}$ & $\begin{array}{l}\text { Bak, XIAP, } \\
\text { Caspase-3/9, } \\
\text { SMAC/DIABLO }\end{array}$ & $\begin{array}{l}\text { miR-27a, via BAK-SMAC/DIABLO-XIAP axis, could } \\
\text { regulate the sensitivity of BC cells to cisplatin treatment. } \\
\text { This miRNA suppresses the apoptosis of breast cancer } \\
\text { cells through regulation of the BAK-SMAC/DIABLO-XIAP } \\
\text { axis }\end{array}$ & (23) \\
\hline miR-32 & Up & $\begin{array}{l}27 \text { pairs of } B C \text { and } \\
\text { ANTs }\end{array}$ & $\begin{array}{l}\text { MCF-10A, MCF-7, } \\
\text { MDA-MB-231 }\end{array}$ & FBXW7 & $\begin{array}{l}\text { miR-32, by targeting FBXW7, could promote cell } \\
\text { proliferation and suppress apoptosis in BC cells }\end{array}$ & (24) \\
\hline miR-34a & - & $\begin{array}{l}\text { Nude mice/human; } \\
222 \text { BC tissues and } \\
\text { ANTs }\end{array}$ & $\begin{array}{l}\text { MCF-10A, 184A1, } \\
\text { SKBR3, T47D, } \\
\text { BT474, } \\
\text { MCF-7, BT-483, BT- } \\
\text { 20, BT549, MDA- } \\
\text { MB-468, } \\
\text { MDA-MB-231 }\end{array}$ & circGFRA1, GFRA1 & $\begin{array}{l}\text { circGFRA1, through sponging miR-34a, could } \\
\text { regulate GFRA1 expression to exert regulatory functions } \\
\text { in triple-negative BC. miR-34a increases the apoptosis of } \\
\text { BC cells }\end{array}$ & (25) \\
\hline miR-100 & - & Nude mice & $\begin{array}{l}\text { MCF-7, T47D, } \\
\text { HCC1954, SK-BR-3, } \\
\text { MDA-MB-453, }\end{array}$ & $\begin{array}{l}\text { MTMR3, p27, Bcl- } \\
\text { 2, Bax, Cyclin-B, } \\
\text { CDK1, Caspase-3/ } \\
7\end{array}$ & miR-100 is involved in regulating the apoptosis of $\mathrm{BC}$ cell & (26) \\
\hline miR-106a & - & $\begin{array}{l}40 \text { pairs of } B C \text { and } \\
\text { ANTs }\end{array}$ & $\begin{array}{l}\text { MDA-MB-231, MCF- } \\
7\end{array}$ & $\begin{array}{l}\text { P53, Bax, RUNX3, } \\
\text { Bcl-2, ABCG2 }\end{array}$ & $\begin{array}{l}\text { miR-106a, by upregulating } \mathrm{BCl}-2, \mathrm{ABCG} 2 \text {, and p53 and } \\
\text { downregulating Bax and RUNX3, could promote BC cell } \\
\text { proliferation and invasion and inhibit their apoptosis }\end{array}$ & $(27)$ \\
\hline miR-125b & - & - & $\begin{array}{l}\text { MCF-7, MCF-7/DR, } \\
\text { MCF-10A, T-47D, } \\
\text { MDA-MB-435 }\end{array}$ & $\begin{array}{l}\text { Mcl-1, Caspase-3, } \\
\text { PARP, smac/ } \\
\text { DIABLO, Cyt C }\end{array}$ & $\begin{array}{l}\text { miR-125b and its synergistic effect on doxorubicin- } \\
\text { inducing cell death, through the downregulation of Mcl-1 } \\
\text { expression, resulting in mitochondria damage, and } \\
\text { caspase-3 activation, could promote cell apoptosis in } \\
\text { BC }\end{array}$ & $(28)$ \\
\hline miR-134 & Down & $\begin{array}{l}77 \text { pairs of } B C \text { and } \\
\text { ANTs }\end{array}$ & Hs578T, Hs578Ts(i)8 & $\begin{array}{l}\text { STAT5B, Hsp90, } \\
\text { Bcl-2 }\end{array}$ & $\begin{array}{l}\text { In extracellular vesicles, miR-134 could increase drug } \\
\text { sensitivity in triple-negative BC and enhance their } \\
\text { apoptosis }\end{array}$ & (29) \\
\hline $\begin{array}{l}\operatorname{miR}-139- \\
5 p\end{array}$ & Down & GEO database & $\begin{array}{l}\text { CBP60419, } \\
\text { CBP60397, } \\
\text { CBP60380, } \\
\text { CBP60402, } \\
\text { CBP60374 }\end{array}$ & $\begin{array}{l}\text { COL11A1, } \\
\text { Caspase-3, Bax, } \\
\text { Bcl-2 }\end{array}$ & $\begin{array}{l}\text { Overexpression of miR-139-5p, by inhibiting the } \\
\text { COL } 11 \mathrm{~A} 1 \text {, could inhibit the proliferation and promote the } \\
\text { apoptosis of BC cells }\end{array}$ & $(30)$ \\
\hline $\begin{array}{l}\operatorname{miR}-139- \\
5 p\end{array}$ & - & - & MCF-7, MCF-7/Doc & $\begin{array}{l}\text { Notch1, Caspase- } \\
\text { 3/7/8/9, MMP2/7/ } \\
\text { 9, Survivin, Akt, } \\
\text { p53 }\end{array}$ & $\begin{array}{l}\text { miR-139-5p, by targeting Notch1, could inhibit the } \\
\text { biological function of BC cells and mediate } \\
\text { chemosensitivity to docetaxel }\end{array}$ & (31) \\
\hline $\begin{array}{l}\mathrm{miR}-143- \\
3 p\end{array}$ & - & 145 BC samples & $\begin{array}{l}\text { MCF-10A, MDA-MB- } \\
435\end{array}$ & $\begin{array}{l}\text { MYBL2, Bax, Bcl- } \\
\text { 2, Cyclin-B1, p21 }\end{array}$ & $\begin{array}{l}\text { miR-143-3p, by targeting MYBL2, could inhibit the } \\
\text { proliferation and induce the apoptosis of BC cells }\end{array}$ & (32) \\
\hline $\begin{array}{l}\text { miR-148a, } \\
m i R-152\end{array}$ & - & $\begin{array}{l}36 \text { pairs of } \mathrm{ER}^{+} \mathrm{BC} \\
\text { with or without }\end{array}$ & MCF-7 & $\begin{array}{l}\text { ALCAM, PARP, } \\
\text { Caspase- } 7 / 9\end{array}$ & $\begin{array}{l}\text { miR-148a and miR-152, by downregulating ALCAM, } \\
\text { could reduce tamoxifen resistance in } \mathrm{ER}^{+} \mathrm{BC}\end{array}$ & (33) \\
\hline
\end{tabular}


TABLE 1 | Continued

\begin{tabular}{|c|c|c|c|c|c|c|}
\hline microRNA & $\begin{array}{l}\text { Expression } \\
\text { pattern }\end{array}$ & Samples & Cell lines & Target/pathway & Function & Referenc \\
\hline & & $\begin{array}{l}\text { tamoxifen treatment, } \\
\text { GEO datasets }\end{array}$ & & & & \\
\hline miR-152 & - & $\begin{array}{l}41 \text { pairs of } B C \text { and } \\
\text { ANTs }\end{array}$ & $\begin{array}{l}\text { MCF-7, MDA-MB- } \\
\text { 231, MCF-10A }\end{array}$ & KIF4A, ZEB1 & $\begin{array}{l}\text { Circular RNA KIF4A, via miR-152/ZEB1 axis, could } \\
\text { promote cell migration and invasion and inhibit apoptosis } \\
\text { in BC }\end{array}$ & (34) \\
\hline miR-193b & - & - & MCF-7, MCF-7/Dox & $M C L-1$ & $\begin{array}{l}\text { miR-193b, by downregulating } M C L-1 \text {, could modulate } \\
\text { the resistance of BC cells to doxorubicin and increase } \\
\text { their apoptosis }\end{array}$ & (35) \\
\hline $\begin{array}{l}\text { miR-199a- } \\
3 p\end{array}$ & - & - & $\begin{array}{l}\text { MDA-MB-231, } \\
\text { MDA-MB-231/DDP }\end{array}$ & TFAM & $\begin{array}{l}\text { miR-199a-3p, by downregulating TFAM, could enhance } \\
\text { BC cell sensitivity to cisplatin }\end{array}$ & $(36)$ \\
\hline miR-200b & Down & $\begin{array}{l}278 \text { pairs of } B C \text { and } \\
\text { ANTs }\end{array}$ & $\begin{array}{l}\text { MDA-MB-231, } \\
\text { SK-BR-3, MCF-7, } \\
\text { MDA-MB-468, } \\
\text { HBL-100 }\end{array}$ & Sp1 & $\begin{array}{l}\text { miR-200b, by targeting Sp1, could induce apoptosis and } \\
\text { inhibit cell proliferation in BC }\end{array}$ & (37) \\
\hline $\begin{array}{l}\operatorname{miR}-205- \\
3 p\end{array}$ & Up & $\begin{array}{l}58 \text { pairs of } B C \text { and } \\
\text { ANTs }\end{array}$ & MCF-7 & $\begin{array}{l}\text { Ezrin, LaminA/C, } \\
\text { Caspase-3, Bcl-2, } \\
\text { Bax }\end{array}$ & $\begin{array}{l}\text { Overexpression of miR-205-3p could promote } \\
\text { proliferation and invasion and reduce the apoptosis of } \\
\text { BC cells and reduce the survival time of patients }\end{array}$ & $(38)$ \\
\hline miR-214 & Down & $\begin{array}{l}31 \text { pairs of } B C \text { and } \\
\text { ANTs }\end{array}$ & $\begin{array}{l}\text { MCF-7, MDA-MB- } \\
\text { 157, MDA-MB-468, } \\
\text { MCF-7/Dox, MDA- } \\
\text { MB-157/Dox }\end{array}$ & $\begin{array}{l}\text { RFWD2, p53, } \\
\text { PUMA, p21, PARP }\end{array}$ & $\begin{array}{l}\text { miR-214, by targeting the RFWD2-p53 axis, could } \\
\text { promote apoptosis and sensitize BC cells to doxorubicin }\end{array}$ & (39) \\
\hline $\begin{array}{l}\operatorname{miR}-214 \\
\text { miR-218 }\end{array}$ & Down & $\begin{array}{l}49 \text { pairs of } B C \text { and } \\
\text { ANTs }\end{array}$ & $\mathrm{MCF}-7$ & - & $\begin{array}{l}\text { Overexpression of miR-214 or miR-218 could suppress } \\
\text { cell proliferation and migration, disturb the cell cycle, and } \\
\text { induce cell apoptosis in BC }\end{array}$ & $(40)$ \\
\hline miR-218 & - & Nude mice & $\begin{array}{l}\text { MCF-7, Cal51, } \\
\text { MCF-7/A02, } \\
\text { CALDOX }\end{array}$ & Survivin, Bax, Bcl-2 & $\begin{array}{l}\text { miR-218, via targeting surviving, could regulate } \\
\text { resistance to chemotherapeutics in } \mathrm{BC}\end{array}$ & $(41)$ \\
\hline miR-221 & Up & $\begin{array}{l}35 \text { pairs of } B C \text { and } \\
\text { ANTs }\end{array}$ & $\begin{array}{l}\text { MDA-MB-231, BT- } \\
\text { 20, MDAMB-435, T- } \\
\text { 47D, MCF-10A }\end{array}$ & BIM-Bax/Bak & $\begin{array}{l}\text { Anti-miR- } 221 \text {, by targeting the Bim-Bax/Bak axis, could } \\
\text { promote the cisplatin-inducing apoptosis in BC }\end{array}$ & $(42)$ \\
\hline $\begin{array}{l}\operatorname{miR}-221 / \\
222\end{array}$ & Up & $\begin{array}{l}\text { Nude mice/human; } 48 \\
\text { pairs of BC and ANTs }\end{array}$ & $\begin{array}{l}\text { MCF-7, MDA-MB- } \\
\text { 231, MDA-MB-453, } \\
\text { SKBR3, MCF-10A }\end{array}$ & GAS5 & $\begin{array}{l}\text { miR-221/222, via IncRNA GAS5 in BC, could promote } \\
\text { tumor growth and suppress apoptosis }\end{array}$ & $(43)$ \\
\hline miR-429 & - & - & $\begin{array}{l}\text { MDA-MB-231, MDA- } \\
\text { MB-468 }\end{array}$ & XIAP & $\begin{array}{l}\text { miR-429, by targeting XIAP, could mediate } \delta \text {-tocotrienol- } \\
\text { induced apoptosis in triple-negative BC cells }\end{array}$ & $(44)$ \\
\hline miR-433 & Down & Mice & 4T1, MCF-7, 293T & $\begin{array}{l}\text { MAPK/ERK, } \\
\text { Rap1a, MMP-9, } \\
\text { Caspase-3, Bax, } \\
\text { Bcl-2, PARP1, p38 }\end{array}$ & $\begin{array}{l}\text { miR-433 via the MAPK signaling pathway, by targeting } \\
\text { Rap1a, could inhibit BC cell growth }\end{array}$ & $(45)$ \\
\hline miR-451 & Down & TCGA database & $\begin{array}{l}\text { MCF-7, SKBR3, } \\
\text { MCF-7/PR, SKBR3/ } \\
\text { PR }\end{array}$ & $\begin{array}{l}\text { YWHAZ, } \beta \text {-catenin, } \\
\text { c-Myc, Cyclin-D1 }\end{array}$ & $\begin{array}{l}\text { miR-451, by regulating } Y W H A Z \text { in SKBR3/PR, drug } \\
\text { resistant, could induce tumor suppression in BC }\end{array}$ & $(46)$ \\
\hline miR-497 & Down & $\begin{array}{l}\text { Nude mice and } \\
\text { human; } 45 \text { pairs of BC } \\
\text { and ANTs }\end{array}$ & $\begin{array}{l}\text { T-74D, MCF-7, } \\
\text { MDA-MB-453, MDA- } \\
\text { MB-468, MDA-MB- } \\
\text { 435, } \\
\text { MCF-10A }\end{array}$ & $\begin{array}{l}\text { Bcl-2, Bax, } \alpha- \\
\text { SMA, } \\
\text { E-cadherin, } \\
\text { Vimentin, } \\
\text { N-cadherin, Slug }\end{array}$ & $\begin{array}{l}\text { miR-497, by targeting slug, could inhibit EMT transition in } \\
\text { BC }\end{array}$ & $(47)$ \\
\hline miR-519d & - & $\begin{array}{l}\text { Nude mice with or } \\
\text { without Cisplatin }\end{array}$ & $\begin{array}{l}\text { T-47D, MCF-7, } \\
\text { SKBR3, } \\
\text { MCF-10A }\end{array}$ & $\begin{array}{l}\text { MCL-1, Caspase- } \\
\text { 3/7/9, } \\
\text { Apaf-1, Smac/ } \\
\text { DIABLO, Cyt C, } \\
\text { Xiap }\end{array}$ & $\begin{array}{l}\text { miR-519d, by downregulating } \mathrm{MCL}-1 \text {, could impede } \\
\text { cisplatin resistance in } \mathrm{BC} \text { stem cells }\end{array}$ & $(48)$ \\
\hline miR-543 & Down & - & $\begin{array}{l}\text { MDA-MB-231, MCF- } \\
7\end{array}$ & $\begin{array}{l}\text { MAPK/ERK, } \\
\text { Cyclin-D1, } \\
\text { Bcl-2, Bax, RSK2, } \\
\text { MSK1, ERK2 }\end{array}$ & $\begin{array}{l}\text { miR-543, by targeting ERK/MAPK, could suppress BC } \\
\text { cell proliferation, block cell cycle, and induce cell } \\
\text { apoptosis }\end{array}$ & $(49)$ \\
\hline $\begin{array}{l}\operatorname{miR}-590- \\
3 p\end{array}$ & - & - & $\begin{array}{l}\text { MCF-7, MDA- } \\
\text { MB231 }\end{array}$ & $\begin{array}{l}\text { Sirtuin-1, p53, p21, } \\
\text { Bax }\end{array}$ & $\begin{array}{l}\text { miR-590-3p, by targeting sirtuin- } 1 \text { and deacetylation of } \\
\text { p53, could suppress cell survival and trigger BC cell } \\
\text { apoptosis }\end{array}$ & $(50)$ \\
\hline miR-1271 & Up & $\begin{array}{l}36 \text { pairs of } B C \text { and } \\
\text { ANTs }\end{array}$ & $\begin{array}{l}\text { MCF-7, MDAMB- } \\
\text { 231, MDA-MB-468, }\end{array}$ & circ-ABCB10 & $\begin{array}{l}\text { circ-ABCB10 could promote BC proliferation and } \\
\text { progression via sponging miR-1271 }\end{array}$ & $(51)$ \\
\hline
\end{tabular}


TABLE 1 | Continued

\begin{tabular}{|c|c|c|c|c|c|c|}
\hline microRNA & $\begin{array}{l}\text { Expression } \\
\text { pattern }\end{array}$ & Samples & Cell lines & Target/pathway & Function & Reference \\
\hline & & & $\begin{array}{l}\text { MDA-MB-453, MCF- } \\
10 A\end{array}$ & & & \\
\hline $\begin{array}{l}\mathrm{miR}-1301- \\
3 p\end{array}$ & Down & $\begin{array}{l}60 \text { pairs of } B C \text { and } \\
\text { ANTs }\end{array}$ & $\begin{array}{l}\text { MCF-7, T47D, MDA- } \\
\text { MB-231, MDA-MB- } \\
\text { 468, MCF-10A }\end{array}$ & $\begin{array}{l}\text { ICT1, CDK4, p21, } \\
\text { Cyclin-D1, Bcl-2, } \\
\text { Bax, Bad }\end{array}$ & $\begin{array}{l}\text { miR-1301-3p, by targeting ICT1, could inhibit BC cell } \\
\text { proliferation by regulating cell cycle progression and } \\
\text { apoptosis }\end{array}$ & (52) \\
\hline $\begin{array}{l}\text { miR-3942- } \\
3 p\end{array}$ & - & $\begin{array}{l}\text { GEO database, } \\
15 \text { pairs of tissues } \\
\text { with or without TCDD } \\
(2,3,7,8 \text { - } \\
\text { tetrachlorodibenzo-p- } \\
\text { dioxin) treatment }\end{array}$ & $\begin{array}{l}\text { MCF-7, MCF-7/ } \\
\text { TCDD }\end{array}$ & $\begin{array}{l}\text { Hsa_circ_0001098 } \\
\text { (BARD1), } \gamma \text {-H2AX, } \\
\text { p53 }\end{array}$ & $\begin{array}{l}\text { Overexpression of circular RNA BARD1 with TCDD } \\
\text { treatment could promote cell apoptosis via miR-3942 in } \\
\text { BC cells }\end{array}$ & (53) \\
\hline miR-4301 & - & $\begin{array}{l}\text { NCBI database, } 30 \\
\text { pairs of BC and ANTs }\end{array}$ & $\begin{array}{l}\text { MDA-MB-231, MCF- } \\
\text { 7, SKBR3, MCF-10A }\end{array}$ & DRD2 & $\begin{array}{l}\text { miR-4301, by negatively regulating DRD2 expression, } \\
\text { could induce cell apoptosis in human } \mathrm{BC} \text { cells }\end{array}$ & (54) \\
\hline miR-4458 & Down & $\begin{array}{l}60 \text { pairs of fresh } \\
\text { TNBC and ANTs }\end{array}$ & $\begin{array}{l}\text { MCF-10A, BT549, } \\
\text { MDA-MB-436 }\end{array}$ & SOCS1 & $\begin{array}{l}\text { miR-4458, by targeting SOCS1, could suppress cell } \\
\text { proliferation and promote cell apoptosis in triple-negative } \\
\text { BC }\end{array}$ & (55) \\
\hline
\end{tabular}

ANTs, adjacent normal tissues.

resistance to anticancer drugs (56). Autophagy is another subject of regulation by miRNAs in breast cancer cells. miR-20a is among the upregulated miRNAs in breast cancer, particularly in triple-negative breast cancer cells. The expression of miR-20a has been negatively correlated with the activity of the autophagy/ lysosome pathway. miR-20a suppresses the basal and nutrient starvation-associated autophagic flux and activity of lysosomalassociated proteolysis. Moreover, this miRNA enhances the intracellular ROS levels and DNA damage response through modulating numerous important regulators of autophagy; among them are BECN1, ATG16L1, and SQSTM1. The expression of miR-20a has been negatively correlated with the expressions of these target genes in breast cancer tissues. Notably, triple-negative cancers have exhibited a particular downregulation of BECN1, ATG16L1, and SQSTM1 genes. The upregulation of miR-20a has also been associated with a higher occurrence of copy number variations and genetic mutations in breast cancer samples. The effects of miR-20a on the enhancement of tumor evolution and growth have also been confirmed in a xenograft model of breast cancer (57). Another study has shown the regulatory effects of miR-20a and miR-20b on the expression of RB1CC1/FIP200. Both miRNAs could decrease the expression of RB1CC1/FIP200 transcripts and proteins. The upregulation of these miRNAs has reduced basal and rapamycin-associated autophagy. Therefore, miR-20a and miR-20b can regulate autophagy through influencing the expression of RB1CC1/FIP200 (58). A high-throughput miRNA sequencing experiment has reported miR-25 as the most important target of isoliquiritigenin (ISL) in inducing autophagy flux. Moreover, mechanistical studies have shown that miR-25 silencing results in cell autophagy through enhancing the expression of ULK1, an early regulator of autophagy initiation. miR-25 upregulation blocks ISLassociated autophagy. ISL has been found to sensitize cancer cells to chemotherapeutic agents as demonstrated by the enhancement in LC3-II levels, decrease in ABCG2 levels, downregulation of miR-25, and activation of ULK1 (59).
The inhibitory roles of miR-26b, miR-129-5p, and miR-200c on autophagy are exerted through the modulation of DRAM1 (60), HMGB1 (61), and UBQLN1 (62) expressions, respectively. Notably, miR-129-5p and miR-200c could attenuate irradiationinduced autophagy and decrease the radioresistance of breast cancer cells through this route (61) (62). Table 2 shows the regulation of autophagy by miRNAs in breast cancer. Figure 2 presents the role of several miRNAs in breast cancer cells via regulating the autophagy pathway.

\section{REGULATION OF EMT BY MIRNAS IN BREAST CANCER}

EMT is a complicated developmental program that permits carcinoma cells to change the epithelial characteristics to mesenchymal features. This alteration permits them to obtain mobility and migration ability. EMT is involved in numerous stages of the metastatic program, from dedifferentiation to aggressiveness (74). TGF- $\beta 1$-induced EMT has been shown to participate in the metastasis of breast cancer cells. This process is regulated by a number of miRNAs-for instance, miR-23a as an upregulated miRNA in breast cancer cells, particularly in metastatic samples, has been shown to be induced by TGF- $\beta 1$. The TGF- $\beta 1$-associated regulation of miR-23a is mediated by direct binding of Smads with the RNA Smad-binding element in miR-23a. The suppression of miR-23a expression has inhibited TGF- $\beta 1$-associated EMT and attenuated the migration, invasiveness, and metastatic ability of breast cancer cells. miR23a can directly inhibit the expression of CDH1, a key modulator of EMT. The miR-23a-mediated suppression of CDH1 has been found to activate $\mathrm{Wnt} / \beta$-catenin signaling. Taken together, miR23 a enhances TGF- $\beta 1$-associated breast cancer metastasis through influencing the expression of $\mathrm{CDH} 1$ and inducing Wnt/ $\beta$-catenin cascade (75). miR-27a is another upregulated miRNA in breast cancer samples and cell lines. The upregulation of miR-27a has increased the migratory potential of breast 


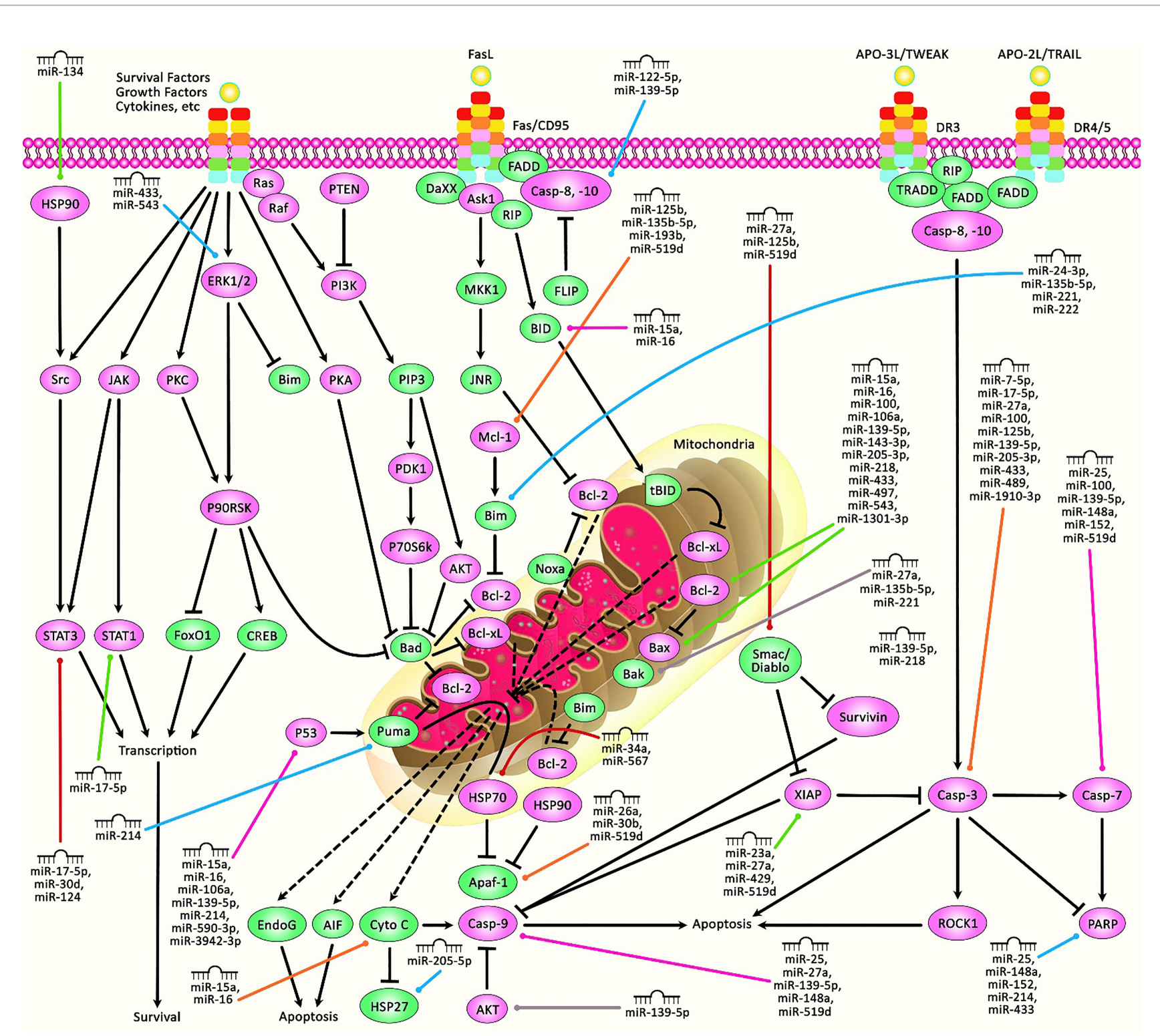

FIGURE 1 | A schematic diagram of the role of miRNAs in triggering the mitochondrial cascade of apoptosis in human breast cancer. Apoptosis pathway could be activated via both extrinsic and intrinsic cascades. The intrinsic pathway is generally occurring through the release of cytochrome c from the mitochondria and modulates mitochondrial outer membrane permeabilization via Bcl-2 family proteins. The activation of extrinsic cascade could be triggered via ligand binding to death receptor, including DR3, DR4, DR5, Fas, and TNF $\alpha$ R. Following that, caspase proteins have a significant part in cleaving target proteins as well as nuclear lamins to elevate DNA degradation, leading to apoptotic cells undergoing phagocytosis. Furthermore, P53, via triggering the upregulation of various proteins containing Bid, Bax, CD95, Puma, and TRAIL-R2, could get effectively involved in activating intrinsic and extrinsic apoptosis cascades. Therefore, any alterations or abnormalities occurring during apoptotic pathways could considerably contribute to the progression of human diseases, including cancer. Previous studies have authenticated that several miRNAs could have a crucial role in regulating the apoptosis pathway in breast cancer. All the information regarding the role of these miRNAs involved in the modulation of breast tumors can be seen in Table $\mathbf{1}$

cancer cells through induction of EMT. FBXW7 has been identified as a downstream target of miR-27a. The overexpression of FBXW7 in breast cancer cells could inhibit EMT and the migratory aptitude of these cells. Therefore, miR-27a can regulate the metastatic potential of breast cancer through the suppression of FBXW7 (76). miR-29a has also been found to be upregulated in breast cancer samples in correlation with distant metastasis and poor clinical outcome of patients. miR-29a silencing has suppressed the proliferation and migration of breast cancer cells. Ten eleven translocation 1 (TET1) has been identified as a target of miR-29a. The upregulation of TET1 has attenuated the proliferation and migration of breast cancer cells. The miR-29a-mediated downregulation of TET1 enhances EMT (77). Several upregulated miRNAs in breast cancer, such as 
TABLE 2 | Regulation of autophagy by miRNAs in breast cancer.

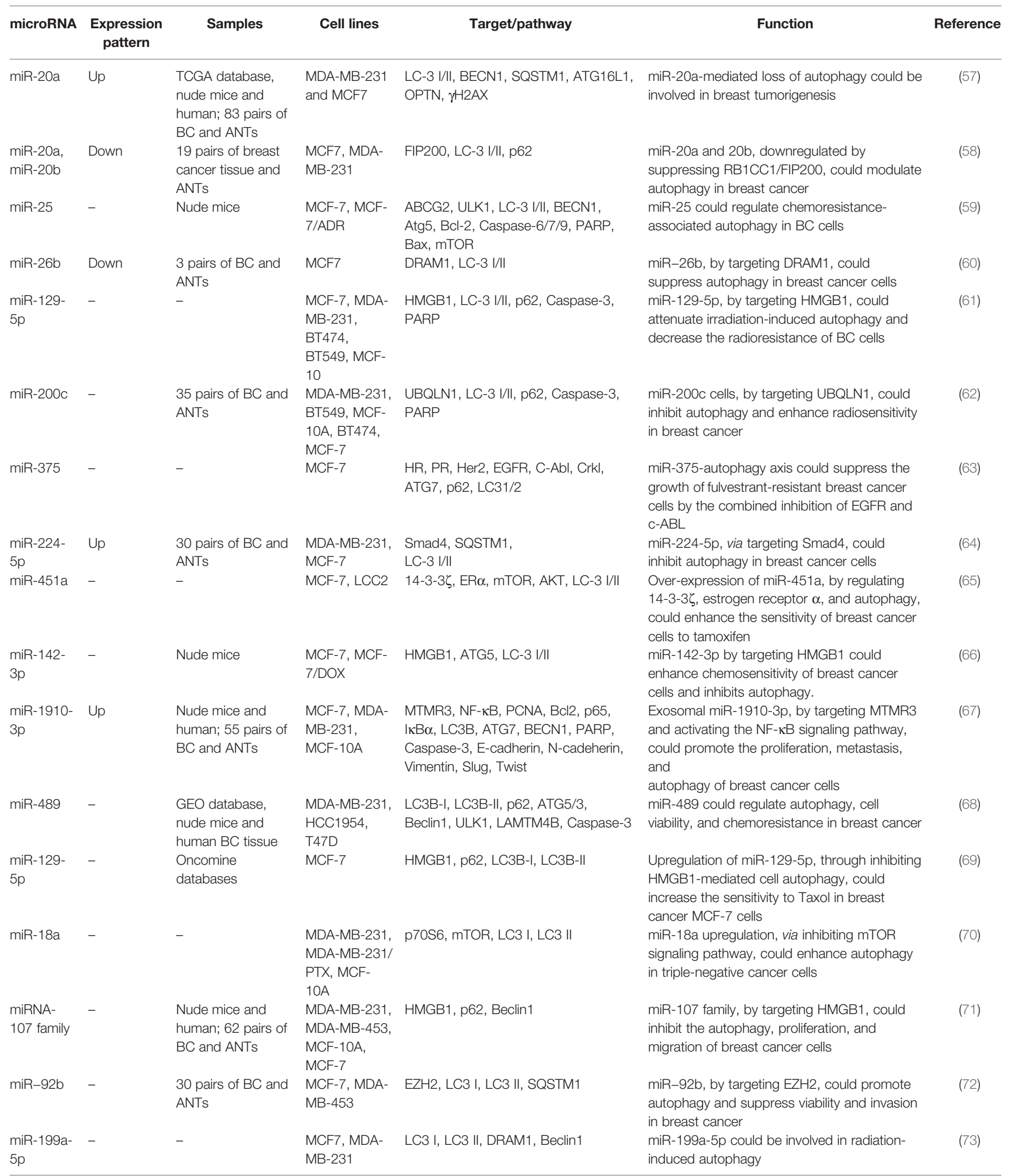

ANTs, adjacent normal tissues. 


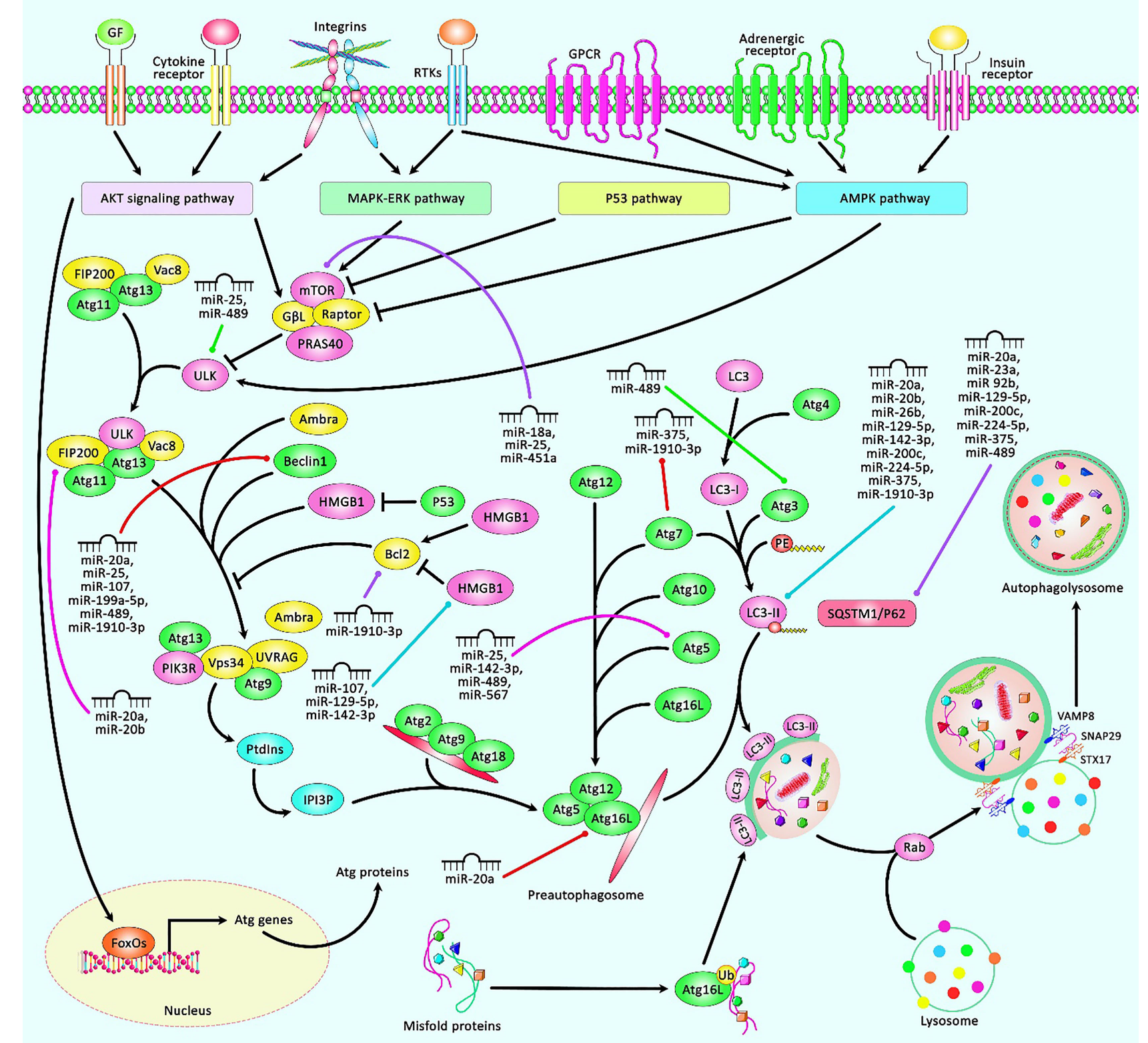

FIGURE 2 | A schematic representation of the role of several miRNAs in regulating the autophagy cascade in human breast cancer. The autophagy pathway is comprised of multiple sequential steps containing sequestration, transport to lysosomes, and degradation. The expression of Atgs could be triggered via AKT, MAKP-ERK, P53, and AMPK pathways. Autophagy is a fundamental substantial biological cascade by removing damaged organelles, but dysregulation of autophagy could contribute to several diseases, including cancers. Accumulating evidence has illustrated that various miRNAs could have a remarkable part in modulating the apoptosis cascade in breast tumors. All the information regarding the role of these miRNAs contributing to the regulation of breast cancer can be seen in Table 2

miR-93, miR-125b, miR-199a-3p, and miR-221, as well as downregulated miRNAs, such as miR-34a, miR-92b, miR-124, miR-138-5p, miR-153, miR-516a-3p, and miR-524-5p, affect the EMT process. Table 3 shows the regulation of EMT by miRNAs in breast cancer. Figure 3 depicts the role of various miRNAs in the modulation of EMT via targeting receptors that convey signals from EMT inducers or multiple EMT components.

\section{REGULATION OF CHEMORESISTANCE BREAST CANCER CELLS BY MIRNAS}

Chemoresistance is a phenotype which is associated with several signaling pathways as well as cellular processes such as apoptosis, autophagy, and EMT. miRNAs have also been found to affect the resistance of breast cancer cells to important chemotherapeutic 
TABLE 3 | Regulation of epithelial-mesenchymal transition (EMT) by miRNAs in breast cancer.

\begin{tabular}{|c|c|c|c|c|c|c|}
\hline microRNA & $\begin{array}{l}\text { Expression } \\
\text { pattern }\end{array}$ & Samples & Cell lines & Target/pathway & Function & Reference \\
\hline miR-23a & Up & $\begin{array}{l}30 \text { pairs of } B C \text { and } \\
\text { ANTs, nude mice }\end{array}$ & $\begin{array}{l}\text { MCF-7, MDA-MB- } \\
468, T 47 D, B T- \\
549 \\
\text { MDA-MB-231 }\end{array}$ & $\begin{array}{l}\mathrm{CDH} 1, \mathrm{Wnt} / \beta- \\
\text { catenin, } \\
\text { E-cadherin }\end{array}$ & $\begin{array}{l}\text { miR-23a, by targeting } \mathrm{CDH} 1 \text { and activating Wnt/ } \beta \text { - } \\
\text { catenin signaling, could promote TGF- } \beta 1 \text {-induced tumor } \\
\text { metastasis in breast cancer }\end{array}$ & (75) \\
\hline $\mathrm{miR}-27 \mathrm{a}$ & Up & $\begin{array}{l}20 \text { pairs of } B C \text { and } \\
\text { ANTs }\end{array}$ & $\begin{array}{l}\text { MDA-MB-231, } \\
\text { SKBR3, MCF-12A }\end{array}$ & $\begin{array}{l}\text { FBXW7, ZEB1, Snail, } \\
\text { Vimentin, E-Cadherin, } \\
\text { N-Cadherin }\end{array}$ & $\begin{array}{l}\text { miR-27a, by inducing EMT in a FBXW7-dependent } \\
\text { manner, could promote human breast cancer cell } \\
\text { migration }\end{array}$ & (76) \\
\hline miR-29a & - & $\begin{array}{l}\text { Nude mice and } \\
\text { human; } 60 \text { pairs of } \\
\text { BC and ANTs }\end{array}$ & $\begin{array}{l}\text { MDA-231, MDA- } \\
453, \text { MCF-7, } \\
\text { MCF-10 }\end{array}$ & $\begin{array}{l}\text { TET1, CyclinD1, p21, } \\
\text { E-Cadherin, N- } \\
\text { Cadherin, } \\
\text { Fibronectin, Vimentin, } \\
\text { ZEB1, ZEB2 }\end{array}$ & $\begin{array}{l}\text { miR-29a, by targeting ten eleven translocation 1, could } \\
\text { promote cell proliferation and EMT in breast cancer }\end{array}$ & $(77)$ \\
\hline miR-30d & - & - & $\begin{array}{l}\text { BT474, MDA-MB- } \\
\text { 231, HCC197, } \\
\text { MDA-MB-468 }\end{array}$ & $\begin{array}{l}\text { KLF11, STAT3, Bcl- } \\
\text { 2, Bax, Vimentin, } \\
\text { N-cadherin, E- } \\
\text { cadherin }\end{array}$ & $\begin{array}{l}\text { miR-30d, by targeting KLF11 and activating the STAT3 } \\
\text { pathway, could mediate breast cancer invasion, } \\
\text { migration, and EMT }\end{array}$ & (78) \\
\hline $\operatorname{miR}-34 a$ & Down & $\begin{array}{l}48 \text { pairs of } B C \text { and } \\
\text { ANTs }\end{array}$ & $\begin{array}{l}\text { MCF-7, T-47D, } \\
\text { BT-549, MDA- } \\
\text { MB-231, MDA- } \\
\text { MB-435 }\end{array}$ & $\begin{array}{l}\text { SLUG, ZEB1/2, } \\
\text { NOTCH1, TWIST1 }\end{array}$ & $\begin{array}{l}\text { miR-34a could inhibit BC cell migration and invasion via } \\
\text { targeting EMT-inducing transcription factors }\end{array}$ & $(79)$ \\
\hline miR-92b & Down & $\begin{array}{l}51 \text { pairs of } B C \text { and } \\
\text { ANTs }\end{array}$ & $\begin{array}{l}\text { MCF-10A, BT549, } \\
\text { MDAMB-231 }\end{array}$ & $\begin{array}{l}\text { Gabra3, Vimentin, } \\
\text { N-cadherin, E- } \\
\text { cadherin }\end{array}$ & miR-92b, by targeting Gabra3, could inhibit EMT & $(80)$ \\
\hline $\operatorname{miR}-93$ & Up & $\begin{array}{l}16 \text { pairs of } B C \text { and } \\
\text { ANTs }\end{array}$ & $\begin{array}{l}\text { MCF-7, MCF-7/ } \\
\text { ADR }\end{array}$ & $\begin{array}{l}\text { Twist, Snail, } \\
\text { fibronectin, Vimentin, } \\
\text { N-cadherin, } \\
\text { E-cadherin }\end{array}$ & $\begin{array}{l}\text { miR-93 could induce EMT and drug resistance of BC } \\
\text { cells by targeting PTEN }\end{array}$ & $(81)$ \\
\hline$m i R-93-5 p$ & - & - & $\begin{array}{l}\text { MCF-7, MDA-MB- } \\
231, \text { T47D }\end{array}$ & $\begin{array}{l}\text { MKL-1, STAT3, } \\
\text { Vimentin, N-cadherin, } \\
\text { E-cadherin }\end{array}$ & $\begin{array}{l}\text { miR-93-5p, by targeting MKL-1 and STAT3, could } \\
\text { inhibit the EMT of breast cancer cells }\end{array}$ & (82) \\
\hline miR-124 & Down & $\begin{array}{l}30 \text { pairs of } B C \text { and } \\
\text { ANTs }\end{array}$ & $\begin{array}{l}\text { MDA-MB-453, } \\
\text { MDA-MB-231, } \\
\text { BT-549 }\end{array}$ & $\begin{array}{l}\text { Vimentin, N-cadherin, } \\
\text { E-cadherin, ZEB2 }\end{array}$ & $\begin{array}{l}\text { miR-124, by regulating EMT based on ZEB2 target, } \\
\text { could inhibit invasion and metastasis in triple-negative } \\
\text { breast cancer }\end{array}$ & (83) \\
\hline miR-125b & Up & $\begin{array}{l}20 \text { pairs of } B C \text { and } \\
\text { ANTs }\end{array}$ & $\begin{array}{l}\text { MDA-MB-231, } \\
\text { MCF-10A, MCF-7, } \\
\text { MDAMB-468 }\end{array}$ & $\begin{array}{l}\text { Vimentin, E-cadherin, } \\
\text { snail, APC, } \beta \text {-catenin, } \\
\text { cyclin D }\end{array}$ & $\begin{array}{l}\text { miR-125b, via the Wnt/ } \beta \text {-catenin pathway and EMT, } \\
\text { could regulate the proliferation and metastasis of triple- } \\
\text { negative breast cancer cells }\end{array}$ & (84) \\
\hline $\begin{array}{l}\operatorname{miR}-138- \\
5 p\end{array}$ & Down & $\begin{array}{l}\text { TCGA dataset, } 20 \\
\text { pairs of BC and ANTs }\end{array}$ & $\begin{array}{l}\text { MDA-MB-231, } \\
\text { MDA-MB-468, } \\
\text { T47D, } \\
\text { ZR-75-30 }\end{array}$ & $\begin{array}{l}\text { N-cadherin, E- } \\
\text { cadherin, Vimentin, } \\
\text { RHBDD1 }\end{array}$ & $\begin{array}{l}\text { miR-138-5p, by targeting RHBDD1, could inhibit cell } \\
\text { migration, invasion, and EMT in breast cancer }\end{array}$ & (85) \\
\hline miR-153 & Down & $\begin{array}{l}60 \text { pairs of TNBC and } \\
\text { ANTs }\end{array}$ & $\begin{array}{l}\text { SKBR3, BT-549, } \\
\text { MDA-MB-231, } \\
\text { MCF-10A }\end{array}$ & $\begin{array}{l}\text { ZEB2, E-cadherin, } \\
\text { N-cadherin, Vimentin }\end{array}$ & $\begin{array}{l}\text { miR-153, through targeting ZEB2-associated EMT, could } \\
\text { inhibit the progression of triple-negative breast cancer }\end{array}$ & (86) \\
\hline $\begin{array}{l}\text { miR-199a- } \\
3 p\end{array}$ & Up & - & $\begin{array}{l}\text { HCC1806, } \\
\text { HCC1937, } \\
\text { MDA-MB-231, } \\
\text { HMEC-184 }\end{array}$ & $\begin{array}{l}\text { GPER, p21, CDK2, } \\
\text { Cyclin E1, Vimentin, } \\
\text { N-cadherin, E- } \\
\text { cadherin, VEGFA, } \\
\text { Ang II, CD151 }\end{array}$ & $\begin{array}{l}\text { Through CD151/miR-199a-3p bio-axis, the activation of } \\
\text { GPER could inhibit cell proliferation, invasion, and EMT of } \\
\text { triple-negative breast cancer }\end{array}$ & $(87)$ \\
\hline miR-221 & Up & TCGA database & $\begin{array}{l}\text { BT549, HCC1806, } \\
\text { MDA-MB-231, } \\
\text { T47D, } \\
\text { MDA-MB-468, } \\
\text { MCF7, MDA-MB- } \\
\text { 361, SKBR3 }\end{array}$ & $\begin{array}{l}\text { ZEB1, MAPK, UPAR, } \\
\text { Vimentin, HER2, ER, } \\
\text { PR }\end{array}$ & $\begin{array}{l}\text { A combined treatment (MEK1 inhibitor + irradiation) could } \\
\text { decrease the migratory potential of BC cells by reducing } \\
\text { miR-221. This miRNA induces EMT in these cells }\end{array}$ & (88) \\
\hline $\begin{array}{l}\text { miR-365- } \\
3 p\end{array}$ & - & $\begin{array}{l}93 \text { pairs breast } \\
\text { cancer tissue and } \\
\text { ANTs }\end{array}$ & $\begin{array}{l}\text { MCF-7, MDA-MB- } \\
\text { 231, MCF-10A }\end{array}$ & $\begin{array}{l}\text { FOXK1, Vimentin, } \\
\text { N-cadherin, E- } \\
\text { cadherin, Slug, Snail }\end{array}$ & $\begin{array}{l}\text { miR-365-3p, by regulating FOXK1, could promote cell } \\
\text { growth and EMT indicates unfavorable prognosis in } \\
\text { breast cancer }\end{array}$ & (89) \\
\hline $\begin{array}{l}\text { miR-516a- } \\
3 p\end{array}$ & Down & $\begin{array}{l}\text { Nude mice and } \\
\text { human; } 60 \text { pairs } \\
\text { breast cancer tissue } \\
\text { and ANTs }\end{array}$ & $\begin{array}{l}\text { MDA- MB-231, } \\
\text { MCF-7, HEK293T }\end{array}$ & $\begin{array}{l}\text { Pygo2, Wnt, E- } \\
\text { cadherin, Vimentin, c- } \\
\text { Myc, cyclinD1, } \beta \text { - } \\
\text { catenin }\end{array}$ & $\begin{array}{l}\text { miR-516a-3p, by blocking the Pygo2Mnt signaling } \\
\text { pathway, could inhibit breast cancer cell growth and EMT }\end{array}$ & (90) \\
\hline
\end{tabular}


TABLE 3 | Continued

\begin{tabular}{|c|c|c|c|c|c|c|}
\hline microRNA & $\begin{array}{l}\text { Expression } \\
\text { pattern }\end{array}$ & Samples & Cell lines & Target/pathway & Function & Reference \\
\hline $\begin{array}{l}\text { miR-520c- } \\
3 p\end{array}$ & - & - & $\begin{array}{l}\text { MCF-7 and T47D, } \\
293 T\end{array}$ & $\begin{array}{l}\text { IL-8, E-cadherin, } \\
\text { Vimentin, fibronectin }\end{array}$ & $\begin{array}{l}\text { miR-520c-3p, by targeting IL-8, could negatively regulate } \\
\text { EMT to suppress the invasion and migration of breast } \\
\text { cancer }\end{array}$ & (91) \\
\hline $\begin{array}{l}\text { miR-524- } \\
5 p\end{array}$ & Down & $\begin{array}{l}20 \text { pairs breast } \\
\text { cancer tissue and } \\
\text { ANTs }\end{array}$ & $\begin{array}{l}\text { SK-BR-3, } \\
\text { MDA-MB-453 }\end{array}$ & $\begin{array}{l}\text { FSTL1, MMP2, } \\
\text { MMP9, E-cadherin, } \\
\text { N-cadherin }\end{array}$ & $\begin{array}{l}\text { miR-524-5p, through targeting FSTL1, could suppress } \\
\text { migration, invasion, and EMT }\end{array}$ & (92) \\
\hline miR-622 & - & $\begin{array}{l}\text { GEO and TCGA } \\
\text { dataset }\end{array}$ & $\begin{array}{l}\text { MDA-MB-231, } \\
\text { MCF7 }\end{array}$ & $\begin{array}{l}\text { RNF8, E-cadherin, } \\
\text { ZO-1, Snail }\end{array}$ & $\begin{array}{l}\text { The miR- } 622 \text { induces EMT through modulation of the } \\
\text { expression of RNF8 }\end{array}$ & (93) \\
\hline $\begin{array}{l}\text { miR-6838- } \\
5 p\end{array}$ & - & - & $\begin{array}{l}\text { CC1937, HCC70, } \\
\text { MDA-MB-231, } \\
\text { MDA-MB-436, } \\
\text { MDA-MB-468 }\end{array}$ & $\begin{array}{l}\text { WNT3A, MMP2/9, } \\
\text { E-cadherin, N- } \\
\text { cadherin, Vimentin, } \beta \text { - } \\
\text { catenin, c-myc, } \\
\text { Cyclin-D1 }\end{array}$ & $\begin{array}{l}\text { miR-6838-5p, by targeting WNT3A to inhibit the Wnt } \\
\text { pathway, could suppress cell metastasis and the EMT } \\
\text { process in triple-negative breast cancer }\end{array}$ & (94) \\
\hline
\end{tabular}

ANTs, adjacent normal tissues.

drugs-for instance, miR-7 has been shown to be downregulated in MCF-7 and adriamycin-resistant cells (MCF-7/ADR cells), particularly in MCF-7/ADR cells. The upregulation of miR-7 has enhanced sensitivity of MCF-7/ADR cells to ADR. The downregulation has led to the upregulation of EGFR and PI3K, while the upregulation of miR-7 has been associated with opposite effects. Moreover, the suppression of miR-7 has been associated with the enhancement of proliferation and inhibition of apoptosis. Therefore, miR-7 has been found to affect the resistance of breast cancer cells to ADR, and its upregulation can enhance the effects of ADR through the suppression of EGFR/ PI3K signaling (97). miR-30c is another miRNA that is involved in intrinsic adriamycin resistance in p53-mutated breast cancer (98).

Moreover, another study in breast cancer has shown a correlation between high miR-7 levels and better pathological complete response to paclitaxel/carboplatin. Functionally, miR-7 has been shown to sensitize MCF-7 and MDA-MB-231 cells to the cytotoxic effects of paclitaxel and carboplatin through targeting MRP1 and BCL2. Taken together, miR-7 has been suggested as a predictive marker for the assessment of chemotherapy efficacy and therapeutic target for the enhancement of response of breast cancer patients to chemotherapy (99). The expression assays in an Src inhibitor saracatinib-resistant breast cancer cell line (SK-BR-3/SI) has shown the downregulation of miR-19b-3p in saracatinib-resistant cells compared with saracatinib-sensitive ones. The under-expression of miR-19b-3p not only has been associated with higher IC50 value of saracatinib but also has increased the migratory potential of breast cancer cells. Functionally, miR-19b-3p targets PIK3CA. Thus, the resistance to Src inhibitors might be due to the enhancement of the activity of PI3K/Akt pathway following miR-19b-3p downregulation (100). In addition, miR-34a could affect the sensitivity of breast cancer cells to sunitinib by regulating the Wnt/ $\beta$-catenin signaling pathway (101).

miR-24-3p is another miRNA which can regulate the sensitivity of breast cancer cells to tamoxifen. The upregulation of miR-24-3p has been shown to increase tamoxifen-induced cytotoxicity in breast cancer cells, while its silencing has decreased these effects. Bim has been identified as a target of miR-24-3p in breast cancer. Further experiments have shown the upregulation of miR-24-3p and the downregulation of BIM expression in tamoxifen-resistant MCF7 cells compared with original cells. Moreover, the suppression of miR-24-3p has enhanced the sensitivity of MCF7/TAM cells to tamoxifen through the enhancement of cell apoptosis (102). Besides this, miR-148a and miR-152, by downregulating ALCAM, could reduce tamoxifen resistance in ER+ breast cancer cells (33). miR-375 is another miRNA that could inhibit cancer stem cell phenotype and tamoxifen resistance in human ER+ breast cancer cells through degrading HOXB3 (103). Meanwhile, tamoxifen has been shown to regulate the expressions of miR-29b-1 and miR-29a (104). Table 4 shows the role of miRNAs in the regulation of response of breast cancer to therapeutic agents.

\section{DISCUSSION}

Non-coding RNAs can influence the expression of several groups of mRNAs through different mechanisms, such as modulation of chromatin structure as well as regulation of transcription and translation. miRNAs are mostly exerting their regulatory roles at the post-transcriptional level through binding to different regions of mRNAs to suppress their translation via mRNA degradation or translation inhibition. miRNAs have been found to regulate important aspects of breast carcinogenesis through the regulation of apoptosis, autophagy, and EMT. miRNAs affect the apoptosis of breast cancer cells through several mechanisms; among them are modulation of p53related pathways, expression of caspases, and regulation of response to ROS. Through modulating the expression of EMTrelated genes as well as those influencing cell motility and invasiveness, miRNAs regulate breast cancer metastasis. Notably, miRNAs can also influence the response of breast cancer cells to a wide array of therapeutic agents ranging from conventional chemotherapeutic drugs to tyrosine kinase inhibitors and hormone therapy agents. Based on in vitro 


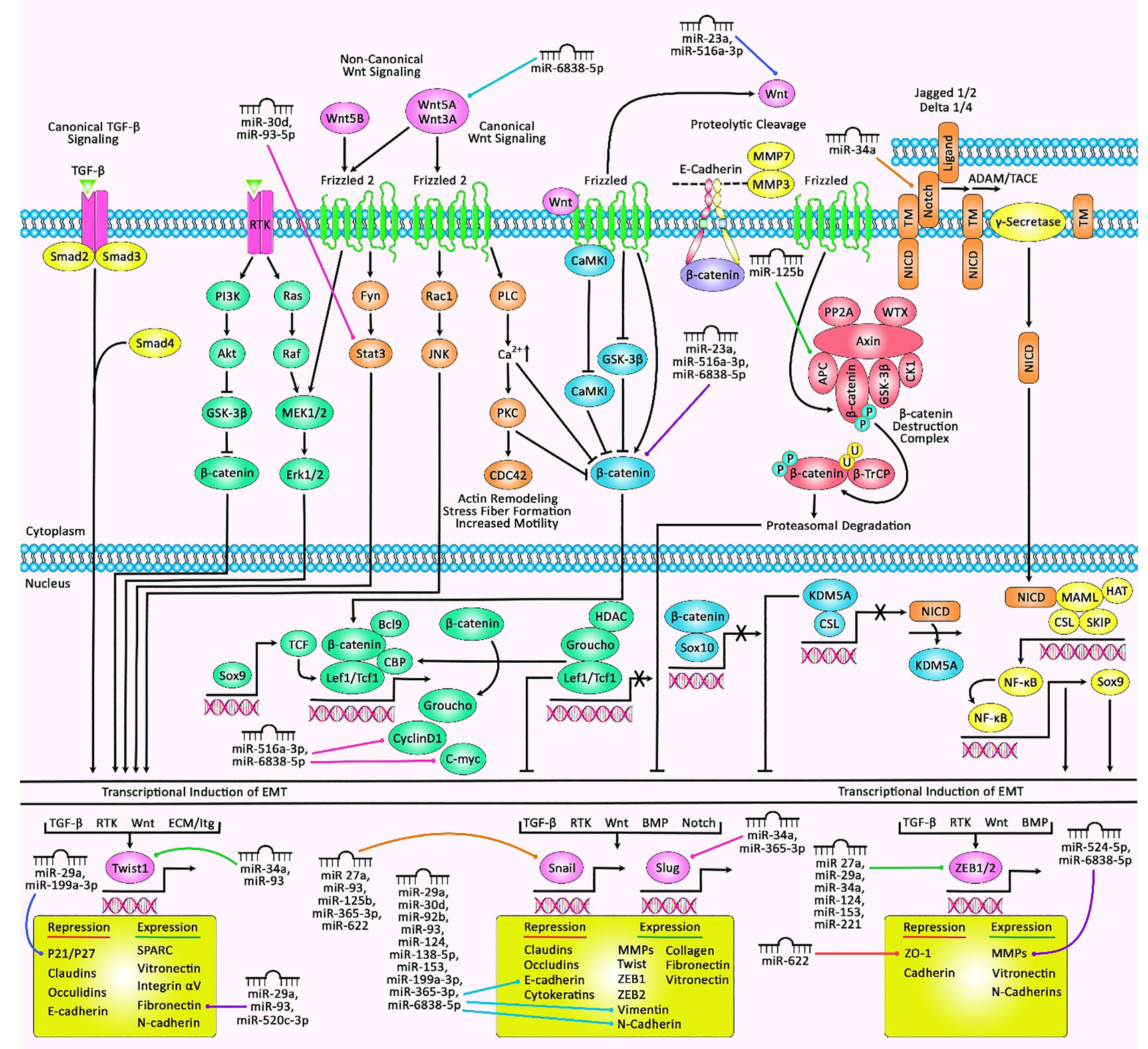

FIGURE 3 | A schematic illustration of the epithelial-mesenchymal transition (EMT)-associated miRNAs and their roles in human breast cancer. EMT is a process that can be induced via a variety of growth factors and cytokines in cancer cells. These elements may be secreted through the cancer cells themselves or via the stromal cells in the tumor microenvironment. These soluble ligands can interact with their cognate receptors, such as TGF- $\beta$ receptors and RTKs, resulting in the activation of several oncogenic pathways (TGF- $\beta$, Wnt/ $\beta$-catenin, integrins, Notch, etc.) which have a significant role in inducing the EMT cascade. Thereby, the activation of EMT can be triggered through the overexpression of selected zinc finger, including ZEB1/2, snail, slug, or basic helix-loop-helix containing TWIST1 transcription factors (95, 96). Recent studies have detected he regulatory role of multiple miRNAs in EMT and breast cancer cells. All the information regarding the influence of these miRNAs in EMT and the control that they exert in major signaling cascades in breast cancer can be seen in Table $\mathbf{3}$.

experiments, miRNAs can regulate the cytotoxic effects of adriamycin, cisplatin, doxorubicin, docetaxel, paclitaxel, gemcitabine, trastuzumab, saracatinib, sunitinib, tamoxifen, and a number of other anti-cancer drugs. In addition to miRNAs whose direct effects on the modulation of response to therapeutic agents have been verified, other miRNAs that regulate cell apoptosis or autophagy can potentially influence therapeutic responses. The modulation of cellular DNA damage response and the activity of cancer stem cells are other routes of participation of miRNAs in the regulation of response of breast cancer cells to chemotherapy. A possible role of miRNAs in the determination of breast cancer stem cells has been suggested through the demonstration of differential expression of miRNAs in CD44+/CD24-/low breast cancer stem cells versus non- 
TABLE 4 | Role of miRNAs in the regulation of response of breast cancer to therapeutic agents.

\begin{tabular}{|c|c|c|c|c|c|c|}
\hline microRNA & $\begin{array}{l}\text { Expression } \\
\text { pattern }\end{array}$ & Samples & Cell lines & Target/pathway & Function & Reference \\
\hline miR-7 & - & - & $\begin{array}{l}\text { MiR-7, MCF-7/ } \\
\text { ADR, MCF-10A }\end{array}$ & EGFR/PI3K & $\begin{array}{l}\text { miR-7 over-expression could inhibit the EGFR/PI3K signaling } \\
\text { pathway to raise their sensitivity to the chemotherapy drug } \\
\text { adriamycin }\end{array}$ & (97) \\
\hline miR-7 & - & $\begin{array}{l}60 \text { pairs of } \mathrm{BC} \\
\text { tissue with or } \\
\text { without paclitaxel } \\
\text { plus carboplatin }\end{array}$ & $\begin{array}{l}\text { MCF-7, MCF- } \\
\text { 7-PR, MDA- } \\
\text { MB-231, } \\
\text { HEK293 }\end{array}$ & MRP1, BCL2 & $\begin{array}{l}\text { miR-7, by suppressing MRP1 and BCL2, could reverse } \\
\text { breast cancer chemoresistance }\end{array}$ & (99) \\
\hline $\begin{array}{l}\text { miR-19b- } \\
3 p\end{array}$ & - & - & $\begin{array}{l}\text { MDA-MB-231, } \\
\text { SK-BR-3, BT- } \\
474 \\
\text { MCF-7 }\end{array}$ & MDR-1,Src, PI3K/Akt & $\begin{array}{l}\text { miR-19b-3p, by regulating the PI3K/Akt pathway, could } \\
\text { inhibit breast cancer cell proliferation and reverse saracatinib } \\
\text { resistance }\end{array}$ & (100) \\
\hline miR-24-3p & Up & $\begin{array}{l}20 \text { pairs of ER+ BC } \\
\text { and ANTs }\end{array}$ & $\begin{array}{l}\text { MCF7, MCF7/ } \\
\text { TAM, T47D }\end{array}$ & $\begin{array}{l}\text { Bim, ER, PR, pS2, } \\
\text { Caspase3, PARP }\end{array}$ & $\begin{array}{l}\text { miR-24-3p overexpression, via direct repression of Bim } \\
\text { expression, could promote the development of tamoxifen } \\
\text { resistance in breast cancer cells }\end{array}$ & (102) \\
\hline $\begin{array}{l}\text { miR-26a, } \\
\text { miR-30b }\end{array}$ & - & - & $\begin{array}{l}\text { BT474 wt, } \\
\text { BT474r, } \\
\text { HCC1954, } \\
\text { MDA-MB-231 }\end{array}$ & $\begin{array}{l}\text { APAF1, CCNE2, } \\
\text { CASP3 }\end{array}$ & $\begin{array}{l}\text { The mentioned microRNAs could be involved in trastuzumab } \\
\text { resistance }\end{array}$ & (105) \\
\hline miR-30c & Up & $\begin{array}{l}\text { TCGA database, } \\
\text { nude mice and } \\
\text { human BC tissue } \\
\text { and ANTs }\end{array}$ & $\begin{array}{l}\text { MCF-7, ZR-75- } \\
1, \\
\text { T-47D, MCF- } \\
\text { 10A, } \\
\text { MDAMB-231 }\end{array}$ & $\begin{array}{l}\text { REV1, FANCF, } \\
\text { FANCD2, RAD51, } \\
\text { ATM, BRCA1, } \\
\text { ERCC1, p53, p21 }\end{array}$ & $\begin{array}{l}\text { miR-30c could be involved in intrinsic adriamycin resistance } \\
\text { in p53-mutated breast cancer }\end{array}$ & (98) \\
\hline miR-34a & - & - & MCF-7 & Wnt/ $\beta$-catenin & $\begin{array}{l}\text { miR-34a, by regulating the Wnt/ } \beta \text {-catenin signaling pathway, } \\
\text { could increase the sensitivity to sunitinib in breast cancer }\end{array}$ & (101) \\
\hline miR-34a & - & - & $\begin{array}{l}\text { MCF-7, MCF- } \\
\text { 10A, } \\
\text { MDA-MB-231, } \\
\text { BT-20, T47-D, } \\
\text { PC3, DU-145, } \\
\text { LNCAP, } \\
\text { OVCAR, SK- } \\
\text { OV-3, HeLa }\end{array}$ & $\begin{array}{l}\text { HDAC1/7, HSP70, } \\
\text { LC3-1I/I }\end{array}$ & $\begin{array}{l}\text { miR-34a, by targeting HDAC1 and } \mathrm{HDAC7} \text {, could reduce } \\
\text { therapy resistance in breast cancer }\end{array}$ & (106) \\
\hline $\begin{array}{l}\operatorname{miR}-122- \\
5 p\end{array}$ & - & - & $\begin{array}{l}\text { MCF-7, } \\
\text { MCF-7-ADR }\end{array}$ & $\begin{array}{l}\text { Bcl-2, CDK2/4/6, } \\
\text { Caspase-8/9 }\end{array}$ & $\begin{array}{l}\text { Resveratrol could increase the sensitivity of BC via targeting } \\
\text { the miR-122-5p/Bcl-2 axis. miR-122-5p enhances the } \\
\text { chemosensitivity of BC cells }\end{array}$ & (107) \\
\hline miR-124 & Up & $\begin{array}{l}\text { Nude mice and } \\
\text { human BC tissue } \\
\text { and ANTs }\end{array}$ & $\begin{array}{l}\text { BT474, MCF7, } \\
\text { SKBR3, MDA- } \\
\text { MB-231 }\end{array}$ & MCT1, LDHA & $\begin{array}{l}\text { Restoration of MCT1 in miR-124-overexpressing cells could } \\
\text { promote resistance to paclitaxel }\end{array}$ & (108) \\
\hline $\mathrm{miR}-125 b$ & - & - & $\begin{array}{l}\text { MCF-7, MCF-7/ } \\
\text { PR, SKBR3, } \\
\text { SKBR3/PR }\end{array}$ & $\begin{array}{l}\text { Sema4C, Snail, Slug, } \\
\text { Vimentin, E-cadherin }\end{array}$ & $\begin{array}{l}\text { miR-125b, by targeting Sema4C, could regulate EMT in } \\
\text { paclitaxel-resistant breast cancer cells }\end{array}$ & (109) \\
\hline $\begin{array}{l}\text { miR-129- } \\
3 p\end{array}$ & - & Nude mice & $\begin{array}{l}\text { MDA-MB-231, } \\
\text { MDA-MB-231/ } \\
\text { Doc, MCF-7 }\end{array}$ & CP110 & $\begin{array}{l}\text { miR-129-3p, by CP110 inhibition, could promote docetaxel } \\
\text { resistance of breast cancer cells }\end{array}$ & (109) \\
\hline miR-137 & - & Nude mice & $\begin{array}{l}\text { MCF-7, MCF-7/ } \\
\text { ADR } \\
\text { (adriamycin- } \\
\text { resistant), } \\
\text { HCC1937, } \\
\text { MDA-MB-468 }\end{array}$ & $\begin{array}{l}\text { DUSP4, E-cadherin, } \\
\text { Vimentin }\end{array}$ & $\begin{array}{l}\text { miR-137, by targeting DUSP4 through inhibition of EMT, } \\
\text { could alleviate doxorubicin resistance in breast cancer }\end{array}$ & (110) \\
\hline $\begin{array}{l}\operatorname{miR}-140- \\
5 p\end{array}$ & - & $\begin{array}{l}\text { Nude mice and } \\
\text { human; } 30 \text { pairs of } \\
\text { BC with or without } \\
\text { paclitaxel }\end{array}$ & $\begin{array}{l}\text { MCF-10A, } \\
\text { MCF-7, MCF-7/ } \\
\text { PTX, MDA-MB- } \\
\text { 231, MDA-MB- } \\
\text { 231/PTX }\end{array}$ & E2F3 & $\begin{array}{l}\text { miR-140-5p, by upregulating E2F3, could improve the } \\
\text { paclitaxel resistance of BC }\end{array}$ & (111) \\
\hline $\begin{array}{l}\text { miR-148a, } \\
\text { miR-152 }\end{array}$ & - & $\begin{array}{l}36 \text { pairs of } \mathrm{ER}^{+} \mathrm{BC} \\
\text { with or without } \\
\text { tamoxifen, GEO } \\
\text { datasets }\end{array}$ & MCF-7 & $\begin{array}{l}\text { ALCAM, PARP, } \\
\text { Caspase- } 7 / 9\end{array}$ & $\begin{array}{l}\text { miR-148a and miR-152, by downregulating ALCAM, could } \\
\text { reduce tamoxifen resistance in } E R^{+} B C\end{array}$ & (33) \\
\hline
\end{tabular}


TABLE 4 | Continued

\begin{tabular}{|c|c|c|c|c|c|c|}
\hline microRNA & $\begin{array}{l}\text { Expression } \\
\text { pattern }\end{array}$ & Samples & Cell lines & Target/pathway & Function & Reference \\
\hline $\begin{array}{l}\operatorname{miR}-155- \\
3 p\end{array}$ & Down & $\begin{array}{l}\text { TCGA database, } \\
\text { nude mice and } \\
\text { human; } 10 \text { pairs of } \\
\text { BC tissue and } \\
\text { ANTs }\end{array}$ & $\begin{array}{l}\text { MCF-10A, } \\
\text { MCF-7, MCF-7/ } \\
\text { PR, SKBR-3, } \\
\text { MDA-MB-231 }\end{array}$ & $\begin{array}{l}\text { MYD88, Bcl-2, Bak-1, } \\
\text { Bax, Caspase-3 }\end{array}$ & $\begin{array}{l}\text { miR-155-3p, by the negative regulation of MYD88, could act } \\
\text { as a tumor suppressor and reverse paclitaxel resistance in } \\
\text { human breast cancer }\end{array}$ & (83) \\
\hline miR-200 & - & - & $\begin{array}{l}\text { MCF7/TAM, } \\
\text { MCF-7, T47D }\end{array}$ & $\begin{array}{l}\text { Vimentin, ZEB1/2, } \\
\text { c-MYB }\end{array}$ & $\begin{array}{l}\text { miR-200, by regulation of MYB, affects tamoxifen resistance } \\
\text { in breast cancer cells }\end{array}$ & $(112)$ \\
\hline miR-200c & - & $\begin{array}{l}\text { GEO database, } \\
\text { nude mice }\end{array}$ & SKBr-3 & $\begin{array}{l}\text { Vimentin, E-cadherin, } \\
\text { smad3, ZEB1 }\end{array}$ & $\begin{array}{l}\text { miR-200c, by targeting ZNF217 and ZEB1, could suppress } \\
\text { TGF-b signaling and counteract trastuzumab resistance and } \\
\text { metastasis in breast cancer }\end{array}$ & (113) \\
\hline miR-222 & Up & $\begin{array}{l}25 \text { pairs of BC with } \\
\text { or without } \\
\text { doxorubicin }\end{array}$ & $\begin{array}{l}\text { MCF-7, MCF- } \\
7-R\end{array}$ & Bim, Caspase-9/3 & $\begin{array}{l}\text { miR-222, by regulation of miR-222/bim pathway, could } \\
\text { promote drug resistance to } \\
\text { doxorubicin in breast cancer }\end{array}$ & (114) \\
\hline miR-326 & - & $\begin{array}{l}35 \text { pairs of } B C \text { and } \\
\text { ANTs }\end{array}$ & $\begin{array}{l}\text { MCF-7, MCF-7/ } \\
\text { VP (VP-16- } \\
\text { resistant MCF- } \\
\text { 7) }\end{array}$ & $\begin{array}{l}\text { MDR-1, MRP-1, } \\
\text { BCRP, }\end{array}$ & $\begin{array}{l}\text { miR-326 overexpression, by transfection of miR-326 mimic, } \\
\text { could downregulate the expression of MRP-1 and also } \\
\text { sensitize MCF-7NP MDR cells to cytotoxic drugs in breast } \\
\text { cancer }\end{array}$ & $(115)$ \\
\hline miR-375 & - & - & MCF-7 & $\begin{array}{l}\text { HOXB3, TWIST, } \\
\text { Cd133, Cd44, MTdH }\end{array}$ & $\begin{array}{l}\text { miR-375, by degrading HOXB3, could inhibit cancer stem } \\
\text { cell phenotype and tamoxifen resistance in human ER- } \\
\text { positive breast cancer }\end{array}$ & (103) \\
\hline miR-381 & Down & $\begin{array}{l}46 \text { pairs of BC } \\
\text { tissue and ANTs }\end{array}$ & $\begin{array}{l}\text { MCF-7, MCF-7/ } \\
\text { DDP MDA-MB- } \\
231 \\
\text { MDA-MB-231/ } \\
\text { DDP }\end{array}$ & MDR1 & $\begin{array}{l}\text { miR-381, by targeting MDR1, could overcome cisplatin } \\
\text { resistance in breast cancer }\end{array}$ & $(116)$ \\
\hline miR-381 & - & $\begin{array}{l}\text { Nude mice and } \\
\text { human; } 48 \text { pairs of } \\
\text { BC tissue and } \\
\text { ANTs, TCGA } \\
\text { database }\end{array}$ & $\begin{array}{l}\text { MCF-7, } \\
\text { MCF-7/CDDP, } \\
\text { MDA-MB-231, } \\
\text { MDA-MB-231/ } \\
\text { CDDP, MCF- } \\
\text { 10A }\end{array}$ & $\mathrm{EZH} 2$ & $\begin{array}{l}\text { EZH2 knockdown, through epigenetically silencing miR-381, } \\
\text { could improve the cisplatin sensitivity of breast cancer cells }\end{array}$ & $(117)$ \\
\hline miR-423 & Up & $\begin{array}{l}\text { Nude mice and } \\
\text { human; } 40 \text { pairs of } \\
\text { BC tissues and } \\
\text { ANTs }\end{array}$ & $\begin{array}{l}\text { MCR-7, } \\
\text { MCF-7/ADR }\end{array}$ & ZFP36, $\beta$-catenin & $\begin{array}{l}\text { miR-423, via the Wnt/ } \beta \text {-catenin signaling pathway, could } \\
\text { inhibit the expression of ZFP36 in breast cancer cells. This } \\
\text { miRNA induces chemoresistance }\end{array}$ & (118) \\
\hline $\operatorname{miR}-489$ & - & $\begin{array}{l}\text { Nude mice, BC } \\
\text { tissue }\end{array}$ & $\begin{array}{l}\text { MCR-7, MCF- } \\
\text { 7/ADM }\end{array}$ & Smad3 & $\begin{array}{l}\text { miR-489 downregulation or gain of Smad3 is a } \\
\text { potential modulator of both chemoresistance and EMT-like } \\
\text { properties in breast cancers. The expression of miR-489 was } \\
\text { decreased in chemoresistance MCF-7/ADM cells compared } \\
\text { with chemosensitive cells. Upregulation of miR-489 } \\
\text { enhanced the chemosensitivity }\end{array}$ & $(119)$ \\
\hline miR-520h & - & - & $\begin{array}{l}\text { MCF-7, } \\
\text { MCF-7/Taxol }\end{array}$ & OTUD3-PTEN, p-AKT & $\begin{array}{l}\text { miR-520h, by targeting the OTUD3-PTEN axis, could } \\
\text { stimulate resistance to paclitaxel }\end{array}$ & $(120)$ \\
\hline $\operatorname{miR}-567$ & Down & $\begin{array}{l}\text { GEO database, } \\
\text { nude mice and } \\
\text { human; } 60 \text { pairs of } \\
\text { BC tissue and } \\
\text { ANTs }\end{array}$ & $\begin{array}{l}\text { SKBR-3, } \\
\text { BT474, SKBR- } \\
\text { 3-TR, } \\
\text { BT474-TR }\end{array}$ & $\begin{array}{l}\text { p62, LC3-I, LC3-II, } \\
\text { ATG5, TSG101, } \\
\text { HSP70 }\end{array}$ & $\begin{array}{l}\text { Exosome-transmitted miR-567 reverses trastuzumab } \\
\text { resistance by inhibiting ATG5 in breast cancer }\end{array}$ & (121) \\
\hline $\mathrm{miR}-873$ & - & - & $\begin{array}{l}\text { MDA-MB-231, } \\
\text { MDA-MB- } \\
\text { 231GEMr, } \\
\text { BT549 }\end{array}$ & $\begin{array}{l}\text { ZEB1, E-cadherin, } \\
\text { AXL, CTGF, CYR61 }\end{array}$ & $\begin{array}{l}\text { Loss of miR-873, via targeting ZEB1, could contribute to } \\
\text { gemcitabine resistance in triple-negative breast cancer }\end{array}$ & $(122)$ \\
\hline miR-1246 & Up & $\begin{array}{l}75 \text { pairs of } B C \text { and } \\
\text { ANTs }\end{array}$ & $\begin{array}{l}\text { MCF-7, } \\
\text { MDA-MB-231, } \\
\text { MCF-10A, } \\
\text { HMLE }\end{array}$ & $\begin{array}{l}\text { CCNG2, tsg101, } \\
\text { calnexin }\end{array}$ & $\begin{array}{l}\text { miR-1246, by targeting CCNG2 in breast cancer, could } \\
\text { promote cell proliferation, invasion, and drug resistance }\end{array}$ & (123) \\
\hline $\begin{array}{l}\operatorname{miR}-15 a \\
\operatorname{miR}-16\end{array}$ & - & - & $\begin{array}{l}\text { MCF-7, } \\
\text { MDAMB-231 }\end{array}$ & $\begin{array}{l}\text { BMl1, RING1A, } \\
\text { RING1B, EZH2, } \\
\gamma \text {-H2AX, Ub-H2A, } \\
\text { CHK2, ATM, RNF8, } \\
\text { RNF168, MEL18, }\end{array}$ & $\begin{array}{l}\text { These miRNAs enhance the sensitivity of breast cancer cells } \\
\text { to DNA damage conferred by doxorubicin }\end{array}$ & (124) \\
\hline
\end{tabular}


TABLE 4 | Continued

\begin{tabular}{|c|c|c|c|c|c|c|}
\hline microRNA & $\begin{array}{l}\text { Expression } \\
\text { pattern }\end{array}$ & Samples & Cell lines & Target/pathway & Function & Reference \\
\hline & & & & $\begin{array}{l}\text { p53BP, BRCA1, p21, } \\
\text { p53, CDK1, Cyclin-B1 }\end{array}$ & & \\
\hline$m i R-27 b$ & - & GEO Datasets & $\begin{array}{l}\text { MCF-7, MCF-7/ } \\
\text { Tams }\end{array}$ & $\begin{array}{l}\text { HMGB3, E-cadherin, } \\
\text { N-cadherin }\end{array}$ & $\begin{array}{l}\text { miR-27b, by targeting HMGB3, could regulate tamoxifen } \\
\text { sensitivity }\end{array}$ & $(125)$ \\
\hline $\begin{array}{l}\text { miR-29b- } \\
\text { 1, miR-29a }\end{array}$ & - & - & $\begin{array}{l}\text { MCF-7, LCC2, } \\
\text { LCC9, LY2 }\end{array}$ & $\mathrm{ER} \alpha, \mathrm{DICER}$ & $\begin{array}{l}\text { Tamoxifen could regulate miR-29b-1 and miR-29a } \\
\text { expression }\end{array}$ & $(104)$ \\
\hline miR-33a & - & - & $\begin{array}{l}\text { SUM149, } \\
\text { SUM159, KPL4 } \\
\text { IBC, } \\
\text { MDA-MB-231 }\end{array}$ & ABCA1 & $\begin{array}{l}\text { miR-33a could decrease high-density lipoprotein-induced } \\
\text { radiation sensitivity }\end{array}$ & (125) \\
\hline miR-107 & - & - & $\begin{array}{l}\text { MCF-7, Taxol/ } \\
\text { miR-107 }\end{array}$ & $\begin{array}{l}\text { Bax, Bcl-2, Akt, } \\
\text { TRIAP1 }\end{array}$ & $\begin{array}{l}\text { miR-107, by targeting TRIAP1, could regulate chemodrug } \\
\text { sensitivity in mammary cancer cell }\end{array}$ & $(126)$ \\
\hline miR-107 & Down & $\begin{array}{l}35 \text { pairs of breast } \\
\text { cancer tissue and } \\
\text { ANTs }\end{array}$ & $\begin{array}{l}\text { MCF-7, MCF-7/ } \\
\text { PTX }\end{array}$ & $\begin{array}{l}\text { TPD52, Wnt/ß-catenin, } \\
\text { Cyclin D1 }\end{array}$ & $\begin{array}{l}\text { miR-107, by targeting TPD52 through Wnt/ } \beta \text {-catenin } \\
\text { signaling pathway, could enhance paclitaxel sensitivity in } \\
\text { breast cancer cells }\end{array}$ & $(127)$ \\
\hline $\begin{array}{l}\text { hsa-miR- } \\
125 a-3 p\end{array}$ & Down & $\begin{array}{l}37 \text { pairs of BC } \\
\text { tissue and normal } \\
\text { adjacent tissue with } \\
\text { or without } \\
\text { doxorubicin } \\
\text { treatment }\end{array}$ & $\begin{array}{l}\text { MECs, MCF-7, } \\
\text { MCF-7/LCC2, } \\
\text { MDA-MB-468, } \\
\text { MDA-MB-231, } \\
\text { MDA-MB-468/ } \\
\text { R, } \\
\text { MCF-7/R, } \\
\text { MDA-MB-468/ } \\
\text { S, } \\
\text { MCF-7/S }\end{array}$ & BRCA1 & $\begin{array}{l}\text { hsa-miR-125a-3p, by regulating BRCA1 signaling, could } \\
\text { function as a tumor suppressor in breast cancer }\end{array}$ & $(128)$ \\
\hline $\begin{array}{l}\operatorname{miR}-124- \\
3 p\end{array}$ & Up & $\begin{array}{l}40 \text { pairs of BC } \\
\text { tissue and ANTs }\end{array}$ & $\begin{array}{l}\text { MCF-7, MCF- } \\
\text { 7-ADR, MCF- } \\
\text { 10A, 293T }\end{array}$ & ABCC4, P-gp & $\begin{array}{l}\text { Overexpression of miR-124-3p and downregulation of } \\
\text { ABCC4 could increase sensitivity to ADR in MCF-7-ADR } \\
\text { cells }\end{array}$ & $(129)$ \\
\hline miR-125a & Up & Nude mice & $\begin{array}{l}\text { MDA-MB-231, } \\
\text { MCF-7, SKBR- } \\
\text { 3, Hs578T, } \\
\text { BT-549, 293T }\end{array}$ & HER2 & $\begin{array}{l}\text { miR-125a, by inducing HER2, could enhance the sensitivity } \\
\text { to trastuzumab in triple-negative breast cancer cells }\end{array}$ & $(130)$ \\
\hline $\begin{array}{l}\text { miR-135b- } \\
5 p\end{array}$ & - & $\begin{array}{l}28 \text { pairs of BC } \\
\text { tissue and ANTs, } \\
\text { nude mice }\end{array}$ & $\begin{array}{l}\text { MCF-7, MCF-7/ } \\
\text { DOXR, MDA- } \\
\text { MB-231, }\end{array}$ & $\begin{array}{l}\text { AGR2, Caspase-2, } \\
\text { Bak, Bim, Bcl-2, Bcl- } \\
\text { xL, Mcl-1 }\end{array}$ & $\begin{array}{l}\text { miR-135b-5p, by targeting anterior gradient } 2 \text {, could } \\
\text { enhance the doxorubicin sensitivity of breast cancer cells }\end{array}$ & (129) \\
\hline miR-144 & - & - & $\begin{array}{l}\text { MDA-MB-231, } \\
\text { SKBR3 }\end{array}$ & $\begin{array}{l}\text { Bax, Bcl-2, N- } \\
\text { Cadherin, Vimentin, } \\
\text { Snail, AKT, PTEN }\end{array}$ & $\begin{array}{l}\text { miR-144, by targeting PTEN/Akt signaling pathway, could } \\
\text { decrease the expression of PTEN and increase the } \\
\text { expression of pAKT in MDA-MB-231 and SKBR3 in breast } \\
\text { cancer cells }\end{array}$ & $(131)$ \\
\hline miR-181a & - & Nude mice & $\begin{array}{l}\text { MCF-7, MCF-7/ } \\
\text { MX }\end{array}$ & $\begin{array}{l}\text { MRP, PGP, LRP, } \\
\text { BCRP }\end{array}$ & $\begin{array}{l}\text { miR-181a, by targeting breast cancer resistance protein } \\
\text { (BCRP/ABCG2), could enhance drug sensitivity in } \\
\text { mitoxantone-resistant breast cancer cells }\end{array}$ & $(132)$ \\
\hline $\begin{array}{l}\mathrm{miR}-181 b- \\
2-3 p\end{array}$ & - & Nude mice & $\begin{array}{l}\text { MDA-MB-231, } \\
\text { MDA-MB-231/ } \\
\text { ADR, } \\
293 \text { T }\end{array}$ & Caspase-3, ABCC3 & $\begin{array}{l}\text { Curcumol, via regulating the miR-181b-2-3p/ABCC3 axis, } \\
\text { could enhance the sensitivity to doxorubicin in triple-negative } \\
\text { breast cancer }\end{array}$ & (133) \\
\hline $\begin{array}{l}\operatorname{miR}-187 \\
-3 p\end{array}$ & Down & $\begin{array}{l}30 \text { pairs of BC } \\
\text { tissue and ANTs }\end{array}$ & MDA-MB-231 & FGF9 & $\begin{array}{l}\text { miR-187-3p, by targeting FGF9 expression, could increase } \\
\text { gemcitabine sensitivity in breast cancer cells }\end{array}$ & $(134)$ \\
\hline miR-190 & - & $\begin{array}{l}\text { Nude mice } \\
\text { treatment with or } \\
\text { without tamoxifen }\end{array}$ & $\begin{array}{l}\text { MCF7, T47D, } \\
\text { MDA-MB-453, } \\
\text { MDA-MB-468, } \\
\text { MDA-MB-231, } \\
\text { MDA-MB-435 }\end{array}$ & $\begin{array}{l}\text { SOX9, Oct-4, Nanog, } \\
\text { ER } \alpha \text {, ZEB1, } \\
\text { Wnt// } \beta \text {-catenin, c-Myc, } \\
\text { Histone-3, TCF4, } \\
\text { Cyclin-D1 }\end{array}$ & $\begin{array}{l}\text { miR-190, by regulating SOX9 expression, could enhance the } \\
\text { sensitivity to endocrine therapy in breast cancer }\end{array}$ & $(135)$ \\
\hline miR-195 & Down & $\begin{array}{l}17 \text { pairs of } B C \text { and } \\
\text { ANTs }\end{array}$ & $\begin{array}{l}\text { MCF-7, MCF-7/ } \\
\text { ADR }\end{array}$ & $\begin{array}{l}\text { Raf-1, Bcl-2, } \\
\text { P-glycoprotein }\end{array}$ & $\begin{array}{l}\text { Upregulation of miR-195, through inhibition of Raf-1, could } \\
\text { increase the sensitivity of breast cancer cells to adriamycin } \\
\text { treatment }\end{array}$ & (136) \\
\hline $\begin{array}{l}\operatorname{miR}-205 \\
-5 p\end{array}$ & Down & $\begin{array}{l}25 \text { pairs of BC } \\
\text { tissue and ANTs }\end{array}$ & $\begin{array}{l}\text { MDA-MB-231, } \\
\text { MDA-MB-231/ } \\
\text { GEM, BT549, } \\
\text { MCF10A }\end{array}$ & ERp29, HSP27 & $\begin{array}{l}\text { miR-205-5p downregulation by ERp29 upregulation could } \\
\text { decrease the gemcitabine sensitivity of breast cancer cells }\end{array}$ & (137) \\
\hline $\begin{array}{l}\mathrm{miR} 302 \mathrm{a} / \\
\mathrm{b} / \mathrm{c} / \mathrm{d}\end{array}$ & - & Nude mice & $\begin{array}{l}\text { MCF-7, MCF-7/ } \\
M X\end{array}$ & BCRP & $\begin{array}{l}\mathrm{miR}-302 \mathrm{a} / \mathrm{b} / \mathrm{c} / \mathrm{d} \text {, through the suppression of BCRP, could } \\
\text { increase drug sensitivity in breast cancer cells }\end{array}$ & (138) \\
\hline
\end{tabular}


TABLE 4 | Continued

\begin{tabular}{|c|c|c|c|c|c|c|}
\hline microRNA & $\begin{array}{l}\text { Expression } \\
\text { pattern }\end{array}$ & Samples & Cell lines & Target/pathway & Function & Reference \\
\hline miR-302b & - & - & $\begin{array}{l}\text { MDA-MB-231, } \\
\text { BT549, T47D }\end{array}$ & $\begin{array}{l}\text { Caspase-3, PARP, } \\
\text { E2F, vinculin, ATM }\end{array}$ & $\begin{array}{l}\text { miR-302b, by regulating E2F1 and the cellular DNA damage } \\
\text { response, could enhance breast cancer cell sensitivity to } \\
\text { cisplatin }\end{array}$ & (139) \\
\hline $\begin{array}{l}\text { miR-378a- } \\
3 p\end{array}$ & Down & $\begin{array}{l}56 \text { pairs of BC } \\
\text { tissue and ANTs, } \\
\text { Omnibus database }\end{array}$ & MCF-7, 293T & GOLT1A & $\begin{array}{l}\text { miR-378a-3p modulates tamoxifen sensitivity in breast } \\
\text { cancer MCF-7 cells through targeting GOLT1A }\end{array}$ & $(140)$ \\
\hline miR-381 & - & Nude mice & $\begin{array}{l}\text { MCF-7, MCF/ } \\
\text { DOX, MDA- } \\
\text { MB-231, MDA- } \\
\text { MB-231/DOX }\end{array}$ & FYN, ERK, p38 & $\begin{array}{l}\text { miR-381, by inactivation of MAPK signaling via FYN, could } \\
\text { induce the sensitivity of breast cancer cells to doxorubicin. }\end{array}$ & (141) \\
\hline miR-638 & - & $\begin{array}{l}78 \text { pairs of BC } \\
\text { tissue and ANTs }\end{array}$ & $\begin{array}{l}\text { T47D, MCF-7, } \\
\text { MDA-MB-231, } \\
\text { MDA-MB-468 }\end{array}$ & STARD10 & $\begin{array}{l}\text { miR-638, via regulating STARD10, could lead to potentiation } \\
\text { of docetaxel sensitivity in BC cells }\end{array}$ & $(142)$ \\
\hline miR-638 & - & - & $\begin{array}{l}\text { MDA-MB-231, } \\
\text { Hs578T, MCF- } \\
\text { 7, T47D, MCF- } \\
\text { 10A }\end{array}$ & BRCA1 & $\begin{array}{l}\text { miR-638, by regulating BRCA1 expression via DNA repair } \\
\text { pathways, could enhance radiation and chemotherapy } \\
\text { sensitivity in TNBC cells }\end{array}$ & $(143)$ \\
\hline $\begin{array}{l}\operatorname{miR}-1207 \\
-5 p\end{array}$ & Up & $\begin{array}{l}30 \text { pairs of TNBC } \\
\text { and ANTs with or } \\
\text { without paclitaxel } \\
\text { treatment }\end{array}$ & $\begin{array}{l}\text { MDA-MB-231, } \\
\text { MDA-MB-436, } \\
\text { MDA-MB-453, } \\
\text { MCF-10A, } \\
\text { MDA-MB-293 }\end{array}$ & LZTS1, Bax, Bcl-2, Akt & $\begin{array}{l}\text { miR-1207-5p, by suppression of LZTS1 expression, could } \\
\text { regulate the sensitivity of triple-negative breast cancer cells } \\
\text { to paclitaxel treatment }\end{array}$ & $(144)$ \\
\hline
\end{tabular}

ANTs, adjacent normal tissues; PTX, paclitaxel; CDDP, cisplatin.

tumorigenic cancer cells (145). This kind of function of miRNAs has a practical significance in the determination of the behavior of breast cancer as well as its response to therapeutic modalities. In addition, a number of anti-cancer agents exert their effects through the modulation of the expression of miRNAs that affect apoptosis or autophagy - for instance, curcumol, via regulating the miR-181b-2-3p/ABCC3 axis, could enhance the sensitivity of triple-negative breast cancer cells to doxorubicin (133). Some miRNAs can affect several aspects of breast carcinogenesis-for instance, miR-34a can affect apoptosis, EMT, and drug resistance. miR-23a has an essential role in the regulation of apoptosis and EMT. Moreover, miR-15a and miR-16a regulate apoptosis and drug resistance. NF- $\mathrm{KB}, \mathrm{mTOR}$, and $\mathrm{Wnt} / \beta$ catenin pathways are among the shared pathways between several miRNAs acting on these processes. Since miRNAs can target multiple transcripts, they can often modulate numerous pathways. Notably, miRNAs exert their inhibitory roles via a complex process which is dependent on cellular constituents, indicating tissue or cell type-specific features (146).

The small molecular size of miRNAs and their capacity in the regulation of the expression of genes participating in the evolution of cancer have endowed miRNAs the potential to influence the treatment of breast cancer (147). As miRNAs can affect both the development of breast cancer and the response of cancerous cells to therapeutic options, intervention with their expression is regarded as an appropriate treatment modality for almost every stage of cancer development and progression. Forced overexpression or suppression of miRNA expression is a possible therapeutic modality for breast cancer. Examples of miRNAantagonism methods are 2'-O-methyl-modified oligonucleotides, locked nucleic acid anti-miRNAs, and cholesterol-conjugated antagomirs. These methods are being used as miRNA-inhibitory tools (148). In fact, the over-expression of miRNAs that induce cell apoptosis, such as miR-7-5p (16), miR-15a, miR-16 (19), and miR-17-5p (20), or inhibit cell cycle progression can suppress the progression of breast cancer. On the other hand, the suppression of expression of oncogenic miRNAs by oligo antisense mechanisms is a treatment modality. In vitro studies have provided a firm evidence for the specificity and efficacy of miRNA-based modalities in the modulation of the expression of target genes, yet future studies should focus on the improvement of delivery systems, enhancement of stability of the prescribed molecules, decreasing off-target effects, and assessment of longterm safety of these molecules (149). Only after solving these issues can miRNA-based therapeutics enter clinical practice.

The identification of the miRNA-associated network and interplay between miRNAs and other types of regulatory transcripts will open new opportunities for diagnostics and therapeutic modalities in breast cancer. System biology methods can be used to predict the role of miRNAs in the determination of response to anti-cancer therapies and prognostic approaches in clinical settings. Targeting miRNAs with essential roles in a drugresistant network has been suggested as a putative approach in overcoming chemoresistance in breast cancer (146). Finally, the combinations of conventional anticancer drugs with antioncogenic miRNA reagents are expected to enhance treatment responses. In fact, the recognition of miRNA profiles in different stages of breast cancer development and development of miRNAbased targeted therapies are two wings of miRNA studies which can introduce novel promising results in clinical settings.

In brief, the contribution of miRNAs in the regulation of cell death, cell motility and invasion, activity of cancer stem cells, regulation of EMT, and modulation of response to therapeutics potentiate miRNAs as proper targets for the treatment of breast 
cancer. However, the clinical application of miRNA-based therapies depends on the effective documentation of miRNA profiles in different subtypes of breast cancer and the construction of the interaction network between miRNAs and genes that regulate breast carcinogenesis and chemoresistance phenotype.

\section{REFERENCES}

1. Sung H, Ferlay J, Siegel RL, Laversanne M, Soerjomataram I, Jemal A, et al. Global Cancer Statistics 2020: GLOBOCAN Estimates of Incidence and Mortality Worldwide for 36 Cancers in 185 Countries. CA: Cancer J Clin (2021) 71(3):209-49. doi: 10.3322/caac.21660

2. Brinton L, Gaudet M, Gierach G. Cancer Epidemiology and Prevention. New York: Oxford University Press (2018).

3. Feng Y, Spezia M, Huang S, Yuan C, Zeng Z, Zhang L, et al. Breast Cancer Development and Progression: Risk Factors, Cancer Stem Cells, Signaling Pathways, Genomics, and Molecular Pathogenesis. Genes Dis (2018) 5 (2):77-106. doi: 10.1016/j.gendis.2018.05.001

4. Bao T, Davidson NE. Gene Expression Profiling of Breast Cancer. Adv Surg (2008) 42:249-60. doi: 10.1016/j.yasu.2008.03.002

5. Elango R, Alsaleh KA, Vishnubalaji R, Manikandan M, Ali AM, El-Aziz A, et al. MicroRNA Expression Profiling on Paired Primary and Lymph Node Metastatic Breast Cancer Revealed Distinct microRNA Profile Associated With LNM. Front Oncol (2020) 10:756. doi: 10.3389/fonc.2020.00756

6. Hamam R, Ali AM, Alsaleh KA, Kassem M, Alfayez M, Aldahmash A, et al. microRNA Expression Profiling on Individual Breast Cancer Patients Identifies Novel Panel of Circulating microRNA for Early Detection. Sci Rep (2016) 6(1):1-8. doi: 10.1038/srep25997

7. Hu Z, Dong J, Wang L-E, Ma H, Liu J, Zhao Y, et al. Serum microRNA Profiling and Breast Cancer Risk: The Use of miR-484/191 as Endogenous Controls. Carcinogenesis (2012) 33(4):828-34. doi: 10.1093/carcin/bgs030

8. Ha M, Kim VN. Regulation of microRNA Biogenesis. Nat Rev Mol Cell Biol (2014) 15(8):509-24. doi: 10.1038/nrm3838

9. Treiber T, Treiber N, Meister G. Regulation of microRNA Biogenesis and its Crosstalk With Other Cellular Pathways. Nat Rev Mol Cell Biol (2019) 20 (1):5-20. doi: 10.1038/s41580-018-0059-1

10. Krol J, Loedige I, Filipowicz W. The Widespread Regulation of microRNA Biogenesis, Function and Decay. Nat Rev Genet (2010) 11(9):597-610. doi: $10.1038 / \mathrm{nrg} 2843$

11. Abak A, Amini S, Estiar MA, Montazeri V, Sakhinia E, Abhari A. Analysis of miRNA-221 Expression Level in Tumors and Marginal Biopsies From Patients With Breast Cancer (Cross-Sectional Observational Study). Clin Lab (2018) 64(1):169-75. doi: 10.7754/Clin.Lab.2017.170821

12. Amini S, Abak A, Estiar MA, Montazeri V, Abhari A, Sakhinia E. Expression Analysis of MicroRNA-222 in Breast Cancer. Clin Lab (2018) 64(4):491-6. doi: 10.7754/Clin.Lab.2017.171002

13. Chen H-T, Liu H, Mao M-J, Tan Y, Mo X-Q, Meng X-J, et al. Crosstalk Between Autophagy and Epithelial-Mesenchymal Transition and its Application in Cancer Therapy. Mol Cancer (2019) 18(1):1-19. doi: 10.1186/s12943-019-1030-2

14. Plati J, Bucur O, Khosravi-Far R. Dysregulation of Apoptotic Signaling in Cancer: Molecular Mechanisms and Therapeutic Opportunities. J Cell Biochem (2008) 104(4):1124-49. doi: 10.1002/jcb.21707

15. Wong RSY. Apoptosis in Cancer: From Pathogenesis to Treatment. J Exp Clin Cancer Res (2011) 30(1):87-. doi: 10.1186/1756-9966-30-87

16. Shi Y, Luo X, Li P, Tan J, Wang X, Xiang T, et al. miR-7-5p Suppresses Cell Proliferation and Induces Apoptosis of Breast Cancer Cells Mainly by Targeting Reg $\gamma$. Cancer Lett (2015) 358(1):27-36. doi: 10.1016/ j.canlet.2014.12.014

17. Gao G, Wong J, Zhang J, Mao I, Shravah J, Wu Y, et al. Proteasome Activator Regy Enhances Coxsackieviral Infection by Facilitating P53 Degradation. J Virol (2010) 84(21):11056-66. doi: 10.1128/JVI.00008-10

18. Li X, Amazit L, Long W, Lonard DM, Monaco JJ, O'Malley BW. UbiquitinAnd ATP-Independent Proteolytic Turnover of P21 by the Reg $\gamma$-Proteasome Pathway. Mol Cell (2007) 26(6):831-42. doi: 10.1016/j.molcel.2007.05.028

\section{AUTHOR CONTRIBUTIONS}

SG-F wrote the draft and revised it. MT designed and supervised the study. AK, AA, HS, and AS collected the data, designed the figures and tables. All the authors read and approved the submitted version.

19. Patel N, Garikapati KR, Ramaiah MJ, Polavarapu KK, Bhadra U, Bhadra MP. miR-15a/miR-16 Induces Mitochondrial Dependent Apoptosis in Breast Cancer Cells by Suppressing Oncogene BMI1. Life Sci (2016) 164:60-70. doi: 10.1016/j.lfs.2016.08.028

20. Liao X-H, Xiang Y, Yu C-X, Li J-P, Li H, Nie Q, et al. STAT3 is Required for MiR-17-5p-Mediated Sensitization to Chemotherapy-Induced Apoptosis in Breast Cancer Cells. Oncotarget (2017) 8(9):15763. doi: 10.18632/ oncotarget. 15000

21. Obexer P, Ausserlechner MJ. X-Linked Inhibitor of Apoptosis Protein-a Critical Death Resistance Regulator and Therapeutic Target for Personalized Cancer Therapy. Front Oncol (2014) 4:197. doi: 10.3389/fonc.2014.00197

22. Chen P, He Y-H, Huang X, Tao S-Q, Wang X-N, Yan H, et al. MiR-23a Modulates X-Linked Inhibitor of Apoptosis-Mediated Autophagy in Human Luminal Breast Cancer Cell Lines. Oncotarget (2017) 8(46):80709. doi: 10.18632/oncotarget.21080

23. Zhou S, Huang Q, Zheng S, Lin K, You J, Zhang X. miR-27a Regulates the Sensitivity of Breast Cancer Cells to Cisplatin Treatment via BAK-SMAC/ DIABLO-XIAP Axis. Tumor Biol (2016) 37(5):6837-45. doi: 10.1007/ s13277-015-4500-1

24. Xia W, Zhou J, Luo H, Liu Y, Peng C, Zheng W, et al. MicroRNA-32 Promotes Cell Proliferation, Migration and Suppresses Apoptosis in Breast Cancer Cells by Targeting FBXW7. Cancer Cell Int (2017) 17(1):1-11. doi: 10.1186/s12935-017-0383-0

25. He R, Liu P, Xie X, Zhou Y, Liao Q, Xiong W, et al. Circgfral and GFRA1 Act as ceRNAs in Triple Negative Breast Cancer by Regulating miR-34a. J Exp Clin Cancer Res (2017) 36(1):1-12. doi: 10.1186/s13046-0170614-1

26. Gong Y, He T, Yang L, Yang G, Chen Y, Zhang X. The Role of miR-100 in Regulating Apoptosis of Breast Cancer Cells. Sci Rep (2015) 5(1):1-13. doi: 10.1038/srep11650

27. You F, Li J, Zhang P, Zhang H, Cao X. Mir106a Promotes the Growth of Transplanted Breast Cancer and Decreases the Sensitivity of Transplanted Tumors to Cisplatin. Cancer Manag Res (2020) 12:233-46. doi: 10.2147/ CMAR.S231375

28. Xie X, Hu Y, Xu L, Fu Y, Tu J, Zhao H, et al. The Role of miR-125bMitochondria-Caspase-3 Pathway in Doxorubicin Resistance and Therapy in Human Breast Cancer. Tumor Biol (2015) 36(9):7185-94. doi: 10.1007/ s13277-015-3438-7

29. O’Brien K, Lowry MC, Corcoran C, Martinez VG, Daly M, Rani S, et al. miR134 in Extracellular Vesicles Reduces Triple-Negative Breast Cancer Aggression and Increases Drug Sensitivity. Oncotarget (2015) 6(32):32774. doi: 10.18632/oncotarget.5192

30. Gu S, Luo J, Yao W. The Regulation of miR-139-5p on the Biological Characteristics of Breast Cancer Cells by Targeting COL11A1. Math Biosci Eng (2020) 17(2):1428-41. doi: 10.3934/mbe.2020073

31. Sun D-w, Mao L, Zhang J, Jiang L-h, Li J, Wu Y, et al. MiR-139-5p Inhibits the Biological Function of Breast Cancer Cells by Targeting Notch1 and Mediates Chemosensitivity to Docetaxel. Biochem Biophys Res Commun (2015) 465(4):702-13. doi: 10.1016/j.bbrc.2015.08.053

32. Chen J, Chen X. MYBL2 Is Targeted by miR-143-3p and Regulates Breast Cancer Cell Proliferation and Apoptosis. Oncol Res (2017) 26(6):913-22. doi: 10.3727/096504017X15135941182107

33. Chen M-J, Cheng Y-M, Chen C-C, Chen Y-C, Shen C-J. MiR-148a and miR152 Reduce Tamoxifen Resistance in ER+ Breast Cancer via Downregulating ALCAM. Biochem Biophys Res Commun (2017) 483(2):840-6. doi: 10.1016/ j.bbrc.2017.01.012

34. Jin Y, Yang L, Li X, Liu F. Circular RNA KIF4A Promotes Cell Migration, Invasion and Inhibits Apoptosis Through miR-152/ZEB1 Axis in Breast Cancer. Diagn Pathol (2020) 15:1-9. doi: 10.1186/s13000-020-00963-7 
35. Long J, Ji Z, Jiang K, Wang Z, Meng G. miR-193b Modulates Resistance to Doxorubicin in Human Breast Cancer Cells by Downregulating MCL-1. BioMed Res Int (2015) 2015. doi: 10.1155/2015/373574

36. Fan X, Zhou S, Zheng M, Deng X, Yi Y, Huang T. MiR-199a-3p Enhances Breast Cancer Cell Sensitivity to Cisplatin by Downregulating TFAM (TFAM). Biomed Pharmacother (2017) 88:507-14. doi: 10.1016/ j.biopha.2017.01.058

37. Yao Y, Hu J, Shen Z, Yao R, Liu S, Li Y, et al. MiR-200b Expression in Breast Cancer: A Prognostic Marker and Act on Cell Proliferation and Apoptosis by Targeting Sp1. J Cell Mol Med (2015) 19(4):760-9. doi: 10.1111/jcmm.12432

38. Qiu C, Huang F, Zhang Q, Chen W, Zhang H. miR-205-3p Promotes Proliferation and Reduces Apoptosis of Breast Cancer MCF-7 Cells and is Associated With Poor Prognosis of Breast Cancer Patients. J Clin Lab Anal (2019) 33(8):e22966. doi: 10.1002/jcla.22966

39. Zhang J, Su B, Gong C, Xi Q, Chao T. miR-214 Promotes Apoptosis and Sensitizes Breast Cancer Cells to Doxorubicin by Targeting the RFWD2-P53 Cascade. Biochem Biophys Res Commun (2016) 478(1):337-42. doi: 10.1016/ j.bbrc.2016.07.054

40. Liu B, Tian Y, Li F, Zhao Z, Jiang X, Zhai C, et al. Tumor-Suppressing Roles of miR-214 and miR-218 in Breast Cancer. Oncol Rep (2016) 35(6):3178-84. doi: 10.3892/or.2016.4749

41. Hu Y, Xu K, Yagüe E. miR-218 Targets Survivin and Regulates Resistance to Chemotherapeutics in Breast Cancer. Breast Cancer Res Treat (2015) 151 (2):269-80. doi: 10.1007/s10549-015-3372-9

42. Ye Z, Hao R, Cai Y, Wang X, Huang G. Knockdown of miR-221 Promotes the Cisplatin-Inducing Apoptosis by Targeting the BIM-Bax/Bak Axis in Breast Cancer. Tumor Biol (2016) 37(4):4509-15. doi: 10.1007/s13277-0154267-4

43. Zong Y, Zhang Y, Sun X, Xu T, Cheng X, Qin Y. miR-221/222 Promote Tumor Growth and Suppress Apoptosis by Targeting lncRNA GAS5 in Breast Cancer. Biosci Rep (2019) 39(1). doi: 10.1042/BSR20181859

44. Wang C, Ju H, Shen C, Tong Z. miR-429 Mediates $\delta$-Tocotrienol-Induced Apoptosis in Triple-Negative Breast Cancer Cells by Targeting XIAP. Int J Clin Exp Med (2015) 8(9):15648.

45. Zhang T, Jiang K, Zhu X, Zhao G, Wu H, Deng G, et al. miR-433 Inhibits Breast Cancer Cell Growth via the MAPK Signaling Pathway by Targeting Rapla. Int J Biol Sci (2018) 14(6):622. doi: 10.7150/ijbs.24223

46. Wang W, Zhang L, Wang Y, Ding Y, Chen T, Wang Y, et al. Involvement of miR-451 in Resistance to Paclitaxel by Regulating YWHAZ in Breast Cancer. Cell Death Dis (2017) 8(10):e3071-e. doi: 10.1038/cddis.2017.460

47. Wu Z, Li X, Cai X, Huang C, Zheng M. miR-497 Inhibits Epithelial Mesenchymal Transition in Breast Carcinoma by Targeting Slug. Tumor Biol (2016) 37(6):7939-50. doi: 10.1007/s13277-015-4665-7

48. Xie Q, Wang S, Zhao Y, Zhang Z, Qin C, Yang X. MiR-519d Impedes Cisplatin-Resistance in Breast Cancer Stem Cells by Down-Regulating the Expression of MCL-1. Oncotarget (2017) 8(13):22003. doi: 10.18632/ oncotarget.15781

49. Chen P, Xu W, Luo Y, Zhang Y, He Y, Yang S, et al. MicroRNA 543 Suppresses Breast Cancer Cell Proliferation, Blocks Cell Cycle and Induces Cell Apoptosis via Direct Targeting of ERK/MAPK. OncoTargets Ther (2017) 10:1423. doi: 10.2147/OTT.S118366

50. Abdolvahabi Z, Nourbakhsh M, Hosseinkhani S, Hesari Z, Alipour M, Jafarzadeh M, et al. MicroRNA-590-3P Suppresses Cell Survival and Triggers Breast Cancer Cell Apoptosis via Targeting Sirtuin-1 and Deacetylation of P53. J Cell Biochem (2019) 120(6):9356-68. doi: 10.1002/jcb.28211

51. Liang H-F, Zhang X-Z, Liu B-G, Jia G-T, Li W-L. Circular RNA CircABCB10 Promotes Breast Cancer Proliferation and Progression Through Sponging miR-1271. Am J Cancer Res (2017) 7(7):1566.

52. Peng X, Yan B, Shen Y. MiR-1301-3p Inhibits Human Breast Cancer Cell Proliferation by Regulating Cell Cycle Progression and Apoptosis Through Directly Targeting ICT1. Breast Cancer (2018) 25(6):742-52. doi: 10.1007/ s12282-018-0881-5

53. Zhao J, Zou H, Han C, Ma J, Zhao J, Tang J. Circlular RNA BARD1 (Hsa_circ_0001098) Overexpression in Breast Cancer Cells With TCDD Treatment Could Promote Cell Apoptosis via miR-3942/BARD1 Axis. Cell Cycle (2018) 17(24):2731-44. doi: 10.1080/15384101.2018.1556058

54. Gholipour N, Ohradanova-Repic A, Ahangari G. A Novel Report of MiR4301 Induces Cell Apoptosis by Negatively Regulating DRD2 Expression in
Human Breast Cancer Cells. J Cell Biochem (2018) 119(8):6408-17. doi: $10.1002 /$ jcb. 26577

55. Liu X, Wang J, Zhang G. miR-4458 Regulates Cell Proliferation and Apoptosis Through Targeting SOCS1 in Triple-Negative Breast Cancer. J Cell Biochem (2019) 120(8):12943-8. doi: 10.1002/jcb.28565

56. Yun CW, Lee SH. The Roles of Autophagy in Cancer. Int J Mol Sci (2018) 19 (11):3466. doi: 10.3390/ijms19113466

57. Liu L, He J, Wei X, Wan G, Lao Y, Xu W, et al. MicroRNA-20a-Mediated Loss of Autophagy Contributes to Breast Tumorigenesis by Promoting Genomic Damage and Instability. Oncogene (2017) 36(42):5874-84. doi: 10.1038/onc. 2017.193

58. Alameen AA, Simioni C, Martelli AM, Zauli G, Ultimo S, McCubrey JA, et al. Healthy CD4+ T Lymphocytes are Not Affected by Targeted Therapies Against the PI3K/Akt/mTOR Pathway in T-Cell Acute Lymphoblastic Leukemia. Oncotarget (2016) 7(34):55690. doi: 10.18632/oncotarget.10984

59. Wang Z, Wang N, Liu P, Chen Q, Situ H, Xie T, et al. MicroRNA-25 Regulates Chemoresistance-Associated Autophagy in Breast Cancer Cells, a Process Modulated by the Natural Autophagy Inducer Isoliquiritigenin. Oncotarget (2014) 5(16):7013. doi: 10.18632/oncotarget.2192

60. Meng C, Liu Y, Shen Y, Liu S, Wang Z, Ye Q, et al. MicroRNA-26b Suppresses Autophagy in Breast Cancer Cells by Targeting DRAM1 mRNA, and is Downregulated by Irradiation. Oncol Lett (2018) 15(2):1435-40. doi: 10.3892/ol.2017.7452

61. Luo J, Chen J, He L. Mir-129-5p Attenuates Irradiation-Induced Autophagy and Decreases Radioresistance of Breast Cancer Cells by Targeting Hmgb1. Med Sci Monit (2015) 21:4122-9. doi: 10.12659/MSM.896661

62. Sun Q, Liu T, Yuan Y, Guo Z, Xie G, Du S, et al. MiR-200c Inhibits Autophagy and Enhances Radiosensitivity in Breast Cancer Cells by Targeting UBQLN1. Int J Cancer (2015) 136(5):1003-12. doi: 10.1002/ ijc. 29065

63. Liu L, Shen W, Zhu Z, Lin J, Fang Q, Ruan Y, et al. Combined Inhibition of EGFR and C-ABL Suppresses the Growth of Fulvestrant-Resistant Breast Cancer Cells Through miR-375-Autophagy Axis. Biochem Biophys Res Commun (2018) 498(3):559-65. doi: 10.1016/j.bbrc.2018.03.019

64. Cheng Y, Li Z, Xie J, Wang P, Zhu J, Li Y, et al. MiRNA-224-5p Inhibits Autophagy in Breast Cancer Cells via Targeting Smad4. Biochem Biophys Res Commun (2018) 506(4):793-8. doi: 10.1016/j.bbrc.2018.10.150

65. Liu Z-R, Song Y, Wan L-H, Zhang Y-Y, Zhou L-M. Over-Expression of miR451a can Enhance the Sensitivity of Breast Cancer Cells to Tamoxifen by Regulating 14-3-3 $\zeta$, Estrogen Receptor $\alpha$, and Autophagy. Life Sci (2016) 149:104-13. doi: 10.1016/j.lfs.2016.02.059

66. Liang L, Fu J, Wang S, Cen H, Zhang L, Mandukhail SR, et al. MiR-142-3p Enhances Chemosensitivity of Breast Cancer Cells and Inhibits Autophagy by Targeting HMGB1. Acta Pharm Sin B (2020) 10(6):1036-46. doi: 10.1016/j.apsb.2019.11.009

67. Wang B, Mao J-h, Wang B-y, Wang L-x, Wen H-y, Xu L-j, et al. Exosomal miR-1910-3p Promotes Proliferation, Metastasis, and Autophagy of Breast Cancer Cells by Targeting MTMR3 and Activating the NF- $\mathrm{kb}$ Signaling Pathway. Cancer Lett (2020) 489:87-99. doi: 10.1016/j.canlet.2020.05.038

68. Soni M, Patel Y, Markoutsa E, Jie C, Liu S, Xu P, et al. Autophagy, Cell Viability, and Chemoresistance are Regulated by miR-489 in Breast Cancer. Mol Cancer Res (2018) 16(9):1348-60. doi: 10.1158/1541-7786.MCR-170634

69. Shi Y, Gong W, Lu L, Wang Y, Ren J. Upregulation of miR-129-5p Increases the Sensitivity to Taxol Through Inhibiting HMGB1-Mediated Cell Autophagy in Breast Cancer MCF-7 Cells. Braz J Med Biol Res (2019) 52 (11). doi: 10.1590/1414-431x20198657

70. Fan Y, Dai Y, Wang X, Ren Y, Han J, Zhang H. MiR-18a Upregulation Enhances Autophagy in Triple Negative Cancer Cells via Inhibiting mTOR Signaling Pathway. Eur Rev Med Pharmacol Sci (2016) 20 (11):2194-200.

71. Ai H, Zhou W, Wang Z, Qiong G, Chen Z, Deng S. microRNAs-107 Inhibited Autophagy, Proliferation, and Migration of Breast Cancer Cells by Targeting HMGB1. J Cell Biochem (2019) 120(5):8696-705. doi: 10.1002/ jcb. 28157

72. Liu F, Sang M, Meng L, Gu L, Liu S, Li J, et al. Mir-92b Promotes Autophagy and Suppresses Viability and Invasion in Breast Cancer by Targeting EZH2. Int J Oncol (2018) 53(4):1505-15. doi: 10.3892/ijo.2018.4486 
73. Yi H, Liang B, Jia J, Liang N, Xu H, Ju G, et al. Differential Roles of miR199a-5p in Radiation-Induced Autophagy in Breast Cancer Cells. FEBS Lett (2013) 587(5):436-43. doi: 10.1016/j.febslet.2012.12.027

74. Ramos FS, Wons L, Cavalli IJ, Ribeiro E. Epithelial-Mesenchymal Transition in Cancer: An Overview. Integr Cancer Sci Ther (2017) 4:1-5.

75. Ma F, Li W, Liu C, Li W, Yu H, Lei B, et al. MiR-23a Promotes TGF- $\beta 1-$ Induced EMT and Tumor Metastasis in Breast Cancer Cells by Directly Targeting $\mathrm{CDH} 1$ and Activating Wnt/ $\beta$-Catenin Signaling. Oncotarget (2017) 8(41):69538. doi: 10.18632/oncotarget.18422

76. Jiang G, Shi W, Fang H, Zhang X. Mir-27a Promotes Human Breast Cancer Cell Migration by Inducing EMT in a FBXW7-dependent Manner. Mol Med Rep (2018) 18(6):5417-26. doi: 10.3892/mmr.2018.9587

77. Pei Y-F, Lei Y, Liu X-Q. MiR-29a Promotes Cell Proliferation and EMT in Breast Cancer by Targeting Ten Eleven Translocation 1. Biochim Biophys Acta (BBA) Molecular Basis Dis (2016) 1862(11):2177-85. doi: 10.1016/ j.bbadis.2016.08.014

78. Han M, Wang Y, Guo G, Li L, Dou D, Ge X, et al. MicroRNA-30d Mediated Breast Cancer Invasion, Migration, and EMT by Targeting KLF11 and Activating STAT3 Pathway. J Cell Biochem (2018) 119(10):8138-45. doi: $10.1002 /$ jcb. 26767

79. Imani S, Wei C, Cheng J, Khan MA, Fu S, Yang L, et al. MicroRNA-34a Targets Epithelial to Mesenchymal Transition-Inducing Transcription Factors (EMT-TFs) and Inhibits Breast Cancer Cell Migration and Invasion. Oncotarget (2017) 8(13):21362. doi: 10.18632/oncotarget.15214

80. Ippen FM, Alvarez-Breckenridge CA, Kuter BM, Fink AL, Bihun IV, Lastrapes M, et al. The Dual PI3K/mTOR Pathway Inhibitor GDC-0084 Achieves Antitumor Activity in PIK3CA-Mutant Breast Cancer Brain Metastases. (2019) 25: (11):3374-83. doi: 10.1158/1078-0432.CCR-18-3049

81. Chu S, Liu G, Xia P, Chen G, Shi F, Yi T, et al. miR-93 and PTEN: Key Regulators of Doxorubicin-Resistance and EMT in Breast Cancer. Oncol Rep (2017) 38(4):2401-7. doi: 10.3892/or.2017.5859

82. Xiang Y, Liao X-H, Yu C-X, Yao A, Qin H, Li J-P, et al. MiR-93-5p Inhibits the EMT of Breast Cancer Cells via Targeting MKL-1 and STAT3. Exp Cell Res (2017) 357(1):135-44. doi: 10.1016/j.yexcr.2017.05.007

83. Zhang L, Chen T, Yan L, Xu H, Wang Y, Li Y, et al. MiR-155-3p Acts as a Tumor Suppressor and Reverses Paclitaxel Resistance via Negative Regulation of MYD88 in Human Breast Cancer. Gene (2019) 700:85-95. doi: 10.1016/j.gene.2019.02.066

84. Nie J, Jiang H-C, Zhou Y-C, Jiang B, He W-J, Wang Y-F, et al. MiR-125b Regulates the Proliferation and Metastasis of Triple Negative Breast Cancer Cells via the Wnt/B-Catenin Pathway and EMT. Biosci Biotechnol Biochem (2019) 83(6):1062-71. doi: 10.1080/09168451.2019.1584521

85. Shi D, Li Y, Fan L, Zhao Q, Tan B, Cui G. Upregulation Of miR-153 Inhibits Triple-Negative Breast Cancer Progression by Targeting ZEB2-Mediated EMT and Contributes to Better Prognosis. OncoTargets Ther (2019) 12:9611. doi: 10.2147/OTT.S223598

86. Makii C, Ikeda Y, Oda K, Uehara Y, Nishijima A, Koso T, et al. Anti-Tumor Activity of Dual Inhibition of Phosphatidylinositol 3-Kinase and MDM2 Against Clear Cell Ovarian Carcinoma. Gynecol Oncol (2019) 155(2):331-9. doi: 10.1016/j.ygyno.2019.08.028

87. Huang R, Li J, Pan F, Zhang B, Yao Y. The Activation of GPER Inhibits Cells Proliferation, Invasion and EMT of Triple-Negative Breast Cancer via CD151/miR-199a-3p Bio-Axis. Am J Trans Res (2020) 12(1):32.

88. Anastasov N, Hirmer E, Klenner M, Ott J, Falkenberg N, Bao X, et al. MEK1 Inhibitor Combined With Irradiation Reduces Migration of Breast Cancer Cells Including miR-221 and ZEB1 EMT Marker Expression. Cancers (2020) 12(12):37600. doi: 10.3390/cancers12123760

89. Gao F, Tian J. FOXK1, Regulated by miR-365-3p, Promotes Cell Growth and EMT Indicates Unfavorable Prognosis in Breast Cancer. OncoTargets Ther (2020) 13:623. doi: 10.2147/OTT.S212702

90. Chi Y, Wang F, Zhang T, Xu H, Zhang Y, Shan Z, et al. miR-516a-3p Inhibits Breast Cancer Cell Growth and EMT by Blocking the Pygo2/Wnt Signalling Pathway. J Cell Mol Med (2019) 23(9):6295-307. doi: 10.1111/ jcmm. 14515

91. Tang C-P, Zhou H-J, Qin J, Luo Y, Zhang T. MicroRNA-520c-3p Negatively Regulates EMT by Targeting IL-8 to Suppress the Invasion and Migration of Breast Cancer. Oncol Rep (2017) 38(5):3144-52. doi: 10.3892/ or.2017.5968
92. Jin T, Zhang Y, Zhang T. MiR-524-5p Suppresses Migration, Invasion, and EMT Progression in Breast Cancer Cells Through Targeting FSTL1. Cancer Biother Radiopharm (2020) 35(10):789-801. doi: 10.1089/cbr.2019.3046

93. Liu C, Min L, Kuang J, Zhu C, Qiu X-Y, Zhu L. Bioinformatic Identification of miR-622 Key Target Genes and Experimental Validation of the miR-622RNF8 Axis in Breast Cancer. Front Oncol (2019) 9:1114-. doi: 10.3389/ fonc. 2019.01114

94. Liu G, Wang P, Zhang H. MiR-6838-5p Suppresses Cell Metastasis and the EMT Process in Triple-Negative Breast Cancer by Targeting WNT3A to Inhibit the Wnt Pathway. J Gene Med (2019) 21(12):e3129. doi: 10.1002/ jgm.3129

95. Sánchez-Tilló E, Liu Y, de Barrios O, Siles L, Fanlo L, Cuatrecasas M, et al. EMT-Activating Transcription Factors in Cancer: Beyond EMT and Tumor Invasiveness. Cell Mol Life Sci (2012) 69(20):3429-56. doi: 10.1007/s00018012-1122-2

96. Huber MA, Kraut N, Beug H. Molecular Requirements for EpithelialMesenchymal Transition During Tumor Progression. Curr Opin Cell Biol (2005) 17(5):548-58. doi: 10.1016/j.ceb.2005.08.001

97. Huang Q, Wu Y, Xing S, Yu Z. Effect of miR-7 on Resistance of Breast Cancer Cells to Adriamycin via Regulating EGFR/PI3K Signaling Pathway. Eur Rev Med Pharmacol Sci (2019) 23(12):5285-92. doi: 10.26355/ eurrev_201906_18195

98. Lin S, Yu L, Song X, Bi J, Jiang L, Wang Y, et al. Intrinsic Adriamycin Resistance in P53-Mutated Breast Cancer is Related to the miR-30c/FANCF/ REV1-Mediated DNA Damage Response. Cell Death Dis (2019) 10(9):1-15. doi: 10.1038/s41419-019-1871-z

99. Hong T, Ding J, Li W. Mir-7 Reverses Breast Cancer Resistance to Chemotherapy by Targeting Mrp1 and Bcl2. OncoTargets Ther (2019) 12:11097. doi: 10.2147/OTT.S213780

100. Jin J, Sun Z, Yang F, Tang L, Chen W, Guan X. miR-19b-3p Inhibits Breast Cancer Cell Proliferation and Reverses Saracatinib-Resistance by Regulating PI3K/Akt Pathway. Arch Biochem Biophys (2018) 645:54-60. doi: 10.1016/ j.abb.2018.03.015

101. Gong L, Shi J, Shang J, Hao J, Du X. Effect of miR-34a on Resistance to Sunitinib in Breast Cancer by Regulating the Wnt/ $\beta$-Catenin Signaling Pathway. Eur Rev Med Pharmacol Sci (2019) 23(3):1151-7. doi: 10.26355/ eurrev_201902_17006

102. Han X, Li Q, Liu C, Wang C, Li Y. Overexpression miR-24-3p Repressed Bim Expression to Confer Tamoxifen Resistance in Breast Cancer. J Cell Biochem (2019) 120(8):12966-76. doi: 10.1002/jcb.28568

103. Fu H, Fu L, Xie C, Zuo W-S, Liu Y-S, Zheng M-Z, et al. miR-375 Inhibits Cancer Stem Cell Phenotype and Tamoxifen Resistance by Degrading HOXB3 in Human ER-Positive Breast Cancer. Oncol Rep (2017) 37 (2):1093-9. doi: 10.3892/or.2017.5360

104. Muluhngwi P, Krishna A, Vittitow SL, Napier JT, Richardson KM, Ellis M, et al. Tamoxifen Differentially Regulates miR-29b-1 and miR-29a Expression Depending on Endocrine-Sensitivity in Breast Cancer Cells. Cancer Lett (2017) 388:230-8. doi: 10.1016/j.canlet.2016.12.007

105. Tormo E, Adam-Artigues A, Ballester S, Pineda B, Zazo S, González-Alonso $\mathrm{P}$, et al. The Role of miR-26a and miR-30b in HER2+ Breast Cancer Trastuzumab Resistance and Regulation of the CCNE2 Gene. Sci Rep (2017) 7(1):1-9. doi: 10.1038/srep41309

106. Wu M-Y, Fu J, Xiao X, Wu J, Wu R-C. MiR-34a Regulates Therapy Resistance by Targeting HDAC1 and HDAC7 in Breast Cancer. Cancer Lett (2014) 354(2):311-9. doi: 10.1016/j.canlet.2014.08.031

107. Zhang W, Jiang H, Chen Y, Ren F. Resveratrol Chemosensitizes AdriamycinResistant Breast Cancer Cells by Modulating miR-122-5p. J Cell Biochem (2019) 120(9):16283-92. doi: 10.1002/jcb.28910

108. Hou L, Zhao Y, Song G-q, Ma Y-h, Jin X-h, Jin S-l, et al. Interfering Cellular Lactate Homeostasis Overcomes Taxol Resistance of Breast Cancer Cells Through the microRNA-124-Mediated Lactate Transporter (MCT1) Inhibition. Cancer Cell Int (2019) 19(1):1-12. doi: 10.1186/s12935-0190904-0

109. Zhang Y, Wang Y, Wei Y, Li M, Yu S, Ye M, et al. MiR-129-3p Promotes Docetaxel Resistance of Breast Cancer Cells via CP110 Inhibition. Sci Rep (2015) 5(1):1-12. doi: 10.1038/srep15424

110. Du F, Yu L, Wu Y, Wang S, Yao J, Zheng X, et al. miR-137 Alleviates Doxorubicin Resistance in Breast Cancer Through Inhibition of Epithelial- 
Mesenchymal Transition by Targeting DUSP4. Cell Death Dis (2019) 10 (12):1-10. doi: 10.1038/s41419-019-2164-2

111. Zang H, Li Y, Zhang X, Huang G. Circ-RNF111 Contributes to Paclitaxel Resistance in Breast Cancer by Elevating E2F3 Expression via miR-140-5p. Thorac Cancer (2020) 11(7):1891-903. doi: 10.1111/1759-7714.13475

112. Gao Y, Zhang W, Liu C, Li G. miR-200 Affects Tamoxifen Resistance in Breast Cancer Cells Through Regulation of MYB. Sci Rep (2019) 9(1):1-6. doi: 10.1038/s41598-019-54289-6

113. Bai WD, Ye XM, Zhang MY, Zhu HY, Xi WJ, Huang X, et al. MiR-200c Suppresses TGF- $\beta$ Signaling and Counteracts Trastuzumab Resistance and Metastasis by Targeting ZNF217 and ZEB1 in Breast Cancer. Int J Cancer (2014) 135(6):1356-68. doi: 10.1002/ijc.28782

114. Dai H, Xu LY, Qian Q, Zhu QW, Chen W-X. MicroRNA-222 Promotes Drug Resistance to Doxorubicin in Breast Cancer via Regulation of miR-222/Bim Pathway. Biosci Rep (2019) 39(7):BSR20190650. doi: 10.1042/BSR20190650

115. Liang Z, Wu H, Xia J, Li Y, Zhang Y, Huang K, et al. Involvement of miR-326 in Chemotherapy Resistance of Breast Cancer Through Modulating Expression of Multidrug Resistance-Associated Protein 1. Biochem Pharmacol (2010) 79(6):817-24. doi: 10.1016/j.bcp.2009.10.017

116. Yi D, Xu L, Wang R, Lu X, Sang J. miR-381 Overcomes Cisplatin Resistance in Breast Cancer by Targeting MDR1. Cell Biol Int (2019) 43(1):12-21. doi: 10.1002/cbin.11071

117. Dou D, Ge X, Wang X, Xu X, Zhang Z, Seng J, et al. EZH2 Contributes to Cisplatin Resistance in Breast Cancer by Epigenetically Suppressing miR-381 Expression. OncoTargets Ther (2019) 12:9627. doi: 10.2147/OTT.S214104

118. Xia W, Liu Y, Du Y, Cheng T, Hu X, Li X. MicroRNA-423 Drug Resistance and Proliferation of Breast Cancer Cells by Targeting ZFP36. OncoTargets Ther (2020) 13:769. doi: 10.2147/OTT.S217745

119. Jiang L, He D, Yang D, Chen Z, Pan Q, Mao A, et al. MiR-489 Regulates Chemoresistance in Breast Cancer via Epithelial Mesenchymal Transition Pathway. FEBS Lett (2014) 588(11):2009-15. doi: 10.1016/j.febslet.2014. 04.024

120. Geng W, Song H, Zhao Q, Dong K, Pu Q, Gao H, et al. Mir-520h Stimulates Drug Resistance to Paclitaxel by Targeting the Otud3-Pten Axis in Breast Cancer. BioMed Res Int (2020) 2020. doi: 10.1155/2020/9512793

121. Han M, Hu J, Lu P, Cao H, Yu C, Li X, et al. Exosome-Transmitted miR-567 Reverses Trastuzumab Resistance by Inhibiting ATG5 in Breast Cancer. Cell Death Dis (2020) 11(1):1-15. doi: 10.1038/s41419-020-2250-5

122. Wang G, Dong Y, Liu H, Ji N, Cao J, Liu A, et al. Loss of Mir-873 Contributes to Gemcitabine Resistance in Triple-Negative Breast Cancer via Targeting ZEB1. Oncol Lett (2019) 18(4):3837-44. doi: 10.3892/ol.2019.10697

123. Li XJ, Ren ZJ, Tang JH, Yu Q. Exosomal MicroRNA MiR-1246 Promotes Cell Proliferation, Invasion and Drug Resistance by Targeting CCNG2 in Breast Cancer. Cell Physiol Biochem (2017) 44(5):1741-8. doi: 10.1159/000485780

124. Patel N, Garikapati KR, Pandita RK, Singh DK, Pandita TK, Bhadra U, et al. miR-15a/miR-16 Down-Regulates BMI1, Impacting Ub-H2A Mediated DNA Repair and Breast Cancer Cell Sensitivity to Doxorubicin. Sci Rep (2017) 7(1):1-17. doi: 10.1038/s41598-017-02800-2

125. Wolfe AR, Bambhroliya A, Reddy JP, Debeb BG, Huo L, Larson R, et al. MiR33a Decreases High-Density Lipoprotein-Induced Radiation Sensitivity in Breast Cancer. Int J Radiat Oncol Biol Phys (2016) 95(2):791-9. doi: 10.1016/ j.ijrobp.2016.01.025

126. Luo Y, Hua T, You X, Lou J, Yang X, Tang N. Effects of MiR-107 on the Chemo-Drug Sensitivity of Breast Cancer Cells. Open Med (2019) 14(1):5965. doi: 10.1515/med-2019-0009

127. Ma C, Shi X, Guo W, Niu J, Wang G. miR-107 Enhances the Sensitivity of Breast Cancer Cells to Paclitaxel. Open Med (2019) 14(1):456-66. doi: 10.1515/med-2019-0049

128. Xu X, Lv Y-g, Yan C-y, Yi J, Ling R. Enforced Expression of hsa-miR-125a$3 p$ in Breast Cancer Cells Potentiates Docetaxel Sensitivity via Modulation of BRCA1 Signaling. Biochem Biophys Res Commun (2016) 479(4):893-900. doi: 10.1016/j.bbrc.2016.09.087

129. Zhang Y, Xia F, Zhang F, Cui Y, Wang Q, Liu H, et al. miR-135b-5p Enhances Doxorubicin-Sensitivity of Breast Cancer Cells Through Targeting Anterior Gradient 2. J Exp Clin Cancer Res (2019) 38(1):1-13. doi: 10.1186/ s13046-019-1024-3

130. Ninio-Many L, Hikri E, Burg Golani T, Stemmer SM, Shalgi R, Ben-Aharon I. miR-125a Induces HER2 Expression and Sensitivity to Trastuzumab in
Triple Negative Breast Cancer Lines. Front Oncol (2020) 10:191. doi: 10.3389/fonc. 2020.00191

131. Yu L, Yang Y, Hou J, Zhai C, Song Y, Zhang Z, et al. MicroRNA-144 Affects Radiotherapy Sensitivity by Promoting Proliferation, Migration and Invasion of Breast Cancer Cells. Oncol Rep (2015) 34(4):1845-52. doi: 10.3892/ or.2015.4173

132. Jiao X, Zhao L, Ma M, Bai X, He M, Yan Y, et al. MiR-181a Enhances Drug Sensitivity in Mitoxantone-Resistant Breast Cancer Cells by Targeting Breast Cancer Resistance Protein (BCRP/Abcg2). Breast Cancer Res Treat (2013) 139(3):717-30. doi: 10.1007/s10549-013-2607-x

133. Zeng C, Fan D, Xu Y, Li X, Yuan J, Yang Q, et al. Curcumol Enhances the Sensitivity of Doxorubicin in Triple-Negative Breast Cancer via Regulating the miR-181b-2-3p-ABCC3 Axis. Biochem Pharmacol (2020) 174:113795. doi: 10.1016/j.bcp.2020.113795

134. Wu Y, Tao L, Liang J, Qiao Y, Liu W, Yu H, et al. Mir-187-3p Increases Gemcitabine Sensitivity in Breast Cancer Cells by Targeting FGF9 Expression. Exp Ther Med (2020) 20(2):952-60. doi: 10.3892/etm.2020.8770

135. Yu Y, Yin W, Yu Z-H, Zhou Y-J, Chi J-R, Ge J, et al. miR-190 Enhances Endocrine Therapy Sensitivity by Regulating SOX9 Expression in Breast Cancer. J Exp Clin Cancer Res (2019) 38(1):1-13. doi: 10.1186/s13046-0191039-9

136. Yang G, Wu D, Zhu J, Jiang O, Shi Q, Tian J, et al. Upregulation of miR-195 Increases the Sensitivity of Breast Cancer Cells to Adriamycin Treatment Through Inhibition of Raf-1. Oncol Rep (2013) 30(2):877-89. doi: 10.3892/ or.2013.2532

137. Ma C, Shi X, Guo W, Feng F, Wang G. Mir-205-5p Downregulation Decreases Gemcitabine Sensitivity of Breast Cancer Cells via ERp29 Upregulation. Exp Ther Med (2019) 18(5):3525-33. doi: 10.1515/med2019-0049

138. Wang Y, Zhao L, Xiao Q, Jiang L, He M, Bai X, et al. miR-302a/B/C/D Cooperatively Inhibit BCRP Expression to Increase Drug Sensitivity in Breast Cancer Cells. Gynecol Oncol (2016) 141(3):592-601. doi: 10.1016/ j.ygyno.2015.11.034

139. Cataldo A, Cheung DG, Balsari A, Tagliabue E, Coppola V, Iorio MV, et al. miR-302b Enhances Breast Cancer Cell Sensitivity to Cisplatin by Regulating E2F1 and the Cellular DNA Damage Response. Oncotarget (2016) 7(1):786. doi: 10.18632/oncotarget.6381

140. Ikeda K, Horie-Inoue K, Ueno T, Suzuki T, Sato W, Shigekawa T, et al. miR378a-3p Modulates Tamoxifen Sensitivity in Breast Cancer MCF-7 Cells Through Targeting GOLT1A. Sci Rep (2015) 5(1):1-12. doi: 10.1038/ srep 13170

141. Mi H, Wang X, Wang F, Li L, Zhu M, Wang N, et al. miR-381 Induces Sensitivity of Breast Cancer Cells to Doxorubicin by Inactivation of MAPK Signaling via FYN. Eur J Pharmacol (2018) 839:66-75. doi: 10.1016/j.ejphar. 2018.09.024

142. Zhao G, Li Y, Wang T. Potentiation of Docetaxel Sensitivity by miR-638 via Regulation of STARD10 Pathway in Human Breast Cancer Cells. Biochem Biophys Res Commun (2017) 487(2):255-61. doi: 10.1016/j.bbrc.2017.04.045

143. Tan X, Peng J, Fu Y, An S, Rezaei K, Tabbara S, et al. miR-638 Mediated Regulation of BRCA1 Affects DNA Repair and Sensitivity to UV and Cisplatin in Triple-Negative Breast Cancer. Breast Cancer Res (2014) 16 (5):1-14. doi: 10.1186/s13058-014-0435-5

144. Hou X, Niu Z, Liu L, Guo Q, Li H, Yang X, et al. Mir-1207-5p Regulates the Sensitivity of Triple-Negative Breast Cancer Cells to Taxol Treatment via the Suppression of LZTS1 Expression. Oncol Lett (2019) 17(1):990-8. doi: 10.3892/ol.2018.9687

145. Shimono Y, Zabala M, Cho RW, Lobo N, Dalerba P, Qian D, et al. Downregulation of miRNA-200c Links Breast Cancer Stem Cells With Normal Stem Cells. cell (2009) 138(3):592-603. doi: 10.1016/j.cell.2009. 07.011

146. Singh R, Mo Y-Y. Role of microRNAs in Breast Cancer. Cancer Biol Ther (2013) 14(3):201-12. doi: 10.4161/cbt.23296

147. Simonson B, Das S. MicroRNA Therapeutics: The Next Magic Bullet? Mini Rev Medicinal Chem (2015) 15(6):467-74. doi: 10.2174/ 1389557515666150324123208

148. Van Rooij E, Kauppinen S. Development of Micro RNA Therapeutics is Coming of Age. EMBO Mol Med (2014) 6(7):851-64. doi: 10.15252/ emmm.201100899 
149. Loh H-Y, Norman BP, Lai K-S, Rahman NMANA, Alitheen NBM, Osman MA. The Regulatory Role of MicroRNAs in Breast Cancer. Int J Mol Sci (2019) 20(19):4940. doi: 10.3390/ijms20194940

Conflict of Interest: The authors declare that the research was conducted in the absence of any commercial or financial relationships that could be construed as a potential conflict of interest.

Publisher's Note: All claims expressed in this article are solely those of the authors and do not necessarily represent those of their affiliated organizations, or those of the publisher, the editors and the reviewers. Any product that may be evaluated in this article, or claim that may be made by its manufacturer, is not guaranteed or endorsed by the publisher.

Copyright (๑) 2021 Ghafouri-Fard, Khanbabapour Sasi, Abak, Shoorei, Khoshkar and Taheri. This is an open-access article distributed under the terms of the Creative Commons Attribution License (CC BY). The use, distribution or reproduction in other forums is permitted, provided the original author(s) and the copyright owner(s) are credited and that the original publication in this journal is cited, in accordance with accepted academic practice. No use, distribution or reproduction is permitted which does not comply with these terms. 